\title{
7. TEXTIL- ÉS BŐRIPAR SZÉKELYFÖLDÖN
}

\section{A CSERGE KÉSZÍTÉSÉRőL}

\section{Mi a cserge?}

A cserge gyapjúból szőtt, két, három vagy négy szélből összevarrt vastag takaró, amely ványoláskor hosszabb szőrt - ún. lomot ereszt, és ekkor nyeri el végleges formáját. Kecske- vagy marhaszőrből (maszókból) szőtt változatát széjas csergének nevezték. Készítése és használata nem terjedt el az egész magyar nyelvterületen. A Kárpát-me- dencében Erdélyben és a moldvai magyarok között volt ismert és használt szőttesfajta. De nem csak náluk. Az erdélyi és a Kárpátokon kívül élő románok körében is nagy hagyományokra tekint vissza. Különösen nevezetesek és kedveltek voltak a máramarosi románok által készített csergék (Gönyey Sándor 1960; Farkas Irén 2008; Kerekes Ibolya 2008.).

Cserge szavunkat A magyar nyelv történeti etimológiai szótára vándorszóként definiálja.

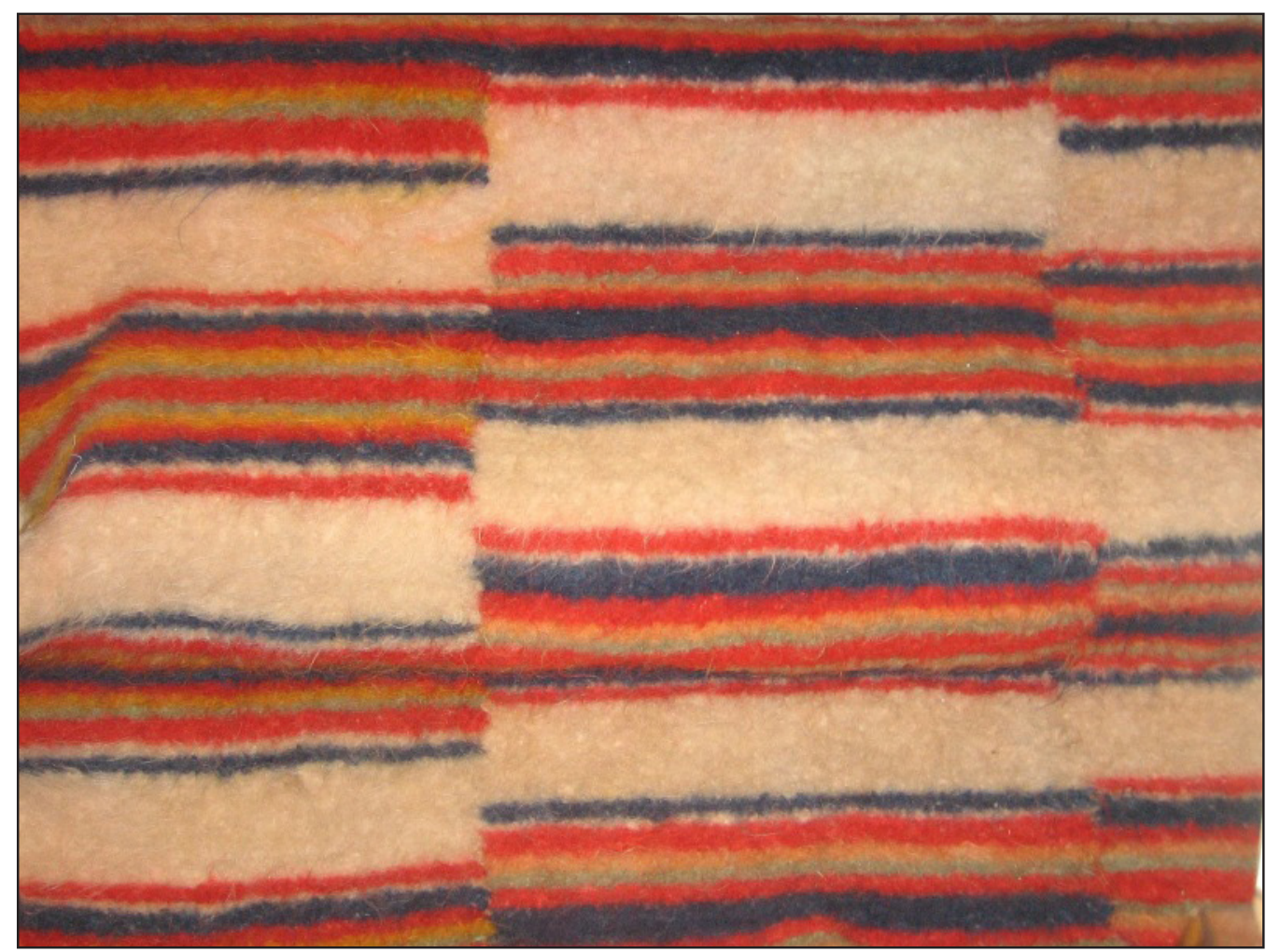

1. kép. Cserge (Kerekes Ibolya felvétele) 
Az oszmán çerge sátrat, a román cergă takarót, pokrócot, az albán cergë durva gyapjútakarót, sátrat, a bolgár чергa vastag gyapjúszőttest, szőnyeget, cigánysátrat jelent, a régi szerb nyelvben pedig a čêrga szónak takaró, pokróc jelentése volt (TESZ 1967. 510-511.). Az Erdélyi magyar szótörténeti tár meghatározása szerint „lompos szövésü gyapjúpokrócfajta" (EMSZT 1978. 115.). A magyar nyelvben a 14-17. században még az állati szőrből, gyapjúból készült sátorponyvát is csergének nevezték, később jobbára már csak a takaró, pokróc, takarózásra használt ágyneműféle jelentésével találkozunk (Palla Ákos 1958; K. Csilléry Klára 1977; EMSZT 1978. 116.). Magyar nyelven első írásos említése 1585-ből való. A későbbiekben feljegyzések egész sora tett említést új és jó öreg, viseltes és egész jó, lyukas és kopott, fehér és fekete, veres csíkos és fehér csíkú csergékről. Megörökítették azt is, hogy még a 15-16. században is voltak olyan egyszerúbb emberek, akik a középkorra jellemző módon, lepedő nélkül, földön vagy padon fekve, csak gyapjúlepedóbe vagy csergébe burkolódzva aludtak. Akik pedig ágyban aludtak, lepedőt terítettek maguk alá, úgy takarództak a vastag, meleg csergével (EMSZT 1978. 115-116; K. Csilléry Klára 1977; Kardalus János 2000. 219; Flórián Mária 2001. 165; Zentai Tünde 2002. 101-102, 149, 268.). Főként Csíkban, Udvarhelyen és Brassó környékén készítették. (Szőcsné Gazda Enikő 2007. 168, 182-182.). ${ }^{1}$

Az évszázadok során Erdély számos vidékén a férjhez menő leányok hozományának egyik alapvető darabja lett. A házasságba vitt cserge mennyisége, nagysága, színe, mintáinak kidolgozottsága a leány vagyoni helyzetét is mutatta (Fél Edit - Hofer Tamás 1969; Kerékgyártó Adrienn, U. 1984). Elsődleges, meleget adó takaró funkcióját a legtöbb helyen mára elveszítette ugyan (szerepét a pap- lan vette át), de lakásdíszként, ágytakaróként számos otthonban napjainkban is találkozhatunk vele (vö. Farkas Irén 2008).

\section{Nyírás}

A juhtartás egyik fontos haszonvétele a gyapjú (Thiering Oszkár 1925. 19-23.). Feldolgozásának rendjében egyes mozzanatoknál tájegységenként, falvanként, sőt falurészenként előfordulhattak különbségek, de a folyamat egésze egységes képet mutat az egész Székelyföldön.

$\mathrm{Az}$ erdélyi juhos gazdák jobbára cigáját vagy rackajuhot tartottak. A havasokon május közepéig meglehetősen hidegek az éjszakák, ezért a hagyományosan Szent György-napon (április 24.) felgyújtött juhsereg téli, vastag bundában vonult föl a havasi legelőre. ${ }^{2} \mathrm{~A}$ sereg összegyüjtését mágikus cselekedetek is kísérhették. Az egyik bánkfalvi asszony elmondása szerint ők láncot kötöttek a kapu alsó részére, közepébe ollót szúrtak. Ezen léptek át a juhok, miközben „Isten vigye szerencsésen, s hozza vissza szerencsésen! Óvja meg a bajtól!" szavakkal szentelt vizet hintettek az állatokra. Más olló helyett fejszét említett, hogy az állat lába erős legyen, elkerülje a baj. Volt, aki zöld ággal hajtotta ki a kapun állatait, hogy jól szaporodjanak (vö. Bálint Sándor 1977. I. 308.).

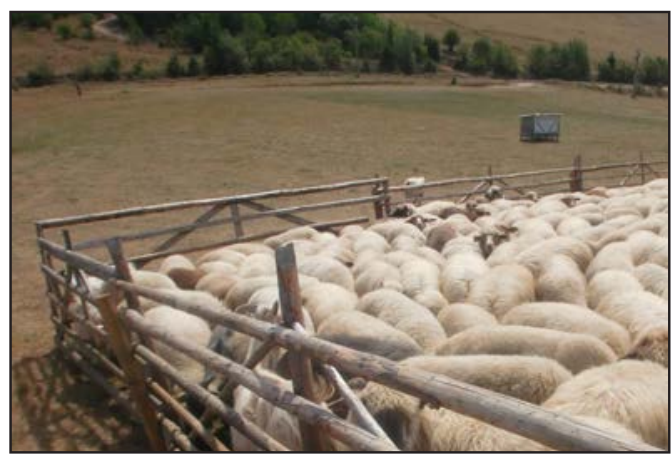

2. kép. Juhok a havasi esztenán (Kerekes Ibolya felvétele) 
A vastag gyapjú segítette a fagyok átvészelését, ám a hidegek elmúltával igyekeztek minél előbb megnyírni a juhokat. Egyrészt, mert vastag bundában könnyebben megrühösödtek, másrészt a meleg elleni védekezésül kezdtek volna megvetkezni, szőrüket elhullatni. A juhnyírás hagyományos ideje május végén, leginkább Orbán napján (május 25.) volt (Szentimrei Judit 1972. 157; Nagy Ödön 1992. 26-27.).

Az öregek emlékezetében sok helyütt még élénken éltek az Orbán-napi havasi nyírő élményei. A reggeli fejés és az otthoni állatok ellátása után a havasi legelők felé vezető út mentén, az esztenabíró által meghatározott helyen és időben találkoztak a családok. Szekerekkel mentek fel az esztenára. Mivel mindenki elsősorban a maga juhait nyírta, és adott időre el kellett készülniük a munkával, ha szükséges volt, a férj és feleség a gyerekek mellett felnőtt segítséget is vitt magával a nyírőbe. A néha két-két és fél órás úton jócskán megehültek, ezért érkezéskor először a tarisznyák kerültek elő. Ettek az otthonról hozott kenyérből, túróból, szalonnából, a pálinkát is „megkóstolták".

Amikor a déli fejésre megérkezett a sereg, akkor kezdődhetett a nyírés. Az emlékezők többsége a déli fejéssel egy időben zajló nyírásról számolt be, de előfordult olyan esztenaközösség is, ahol a fejés befejezése után kezdték nyírni a juhokat. Füljegyek alapján a családok kiválasztották a seregből a maguk juhait. Mindenkinek megvolt a szokása, hogy az állat hasán vagy hátán kezdi a munkát. Aki a hasán kezdett, az lefektette a juhot, egyik kezével az ajakát szorítva földre nyomta a fejét, másik kezében a juhnyíró ollóval a hasától indulva haladt körbe. Ha jól sikerült, akkor egyben teríthette ki a gyapjút. Aki a hátán kezdett, az a lábon álló juhot fogta meg erősen, előbb a gerinc vonalán haladt végig, majd a jobb és bal oldaláról külön-külön nyírta le a gyapjút.

A munkához kétféle ollót használtak. Az egyik típust főként helybeli kovácsok készítették, a másik, ún. csattanósat cigányoktól vásárolták, később mindkettőt boltból szerezték be (vö. Tagán Galimdsán 1939. 233. I. tábla, 2. ábra; Szentimrei Judit 1981. 193; Szolnoky Lajos 1991. 366.). Különösen a csattanós olló használata kívánt ügyességet. Vigyázni kellett ugyanis, hogy a felső él mindig az alsó elé kerüljön, máskülönben az élek eltávolodtak egymástól, s ahelyett, hogy a gyapjút nyírták volna, az állat vagy épp a nyíró bőrét csíphették ki vele. Mivel a juh könnyen szökött, lefogásában a gyerekek is segédkeztek. Ez általában az állat erős megfogását jelentette, de lehetett földre szorítás, a lábak összekötése, illetve cüvekhez vagy a kosár oldalához való kikötés. Tíz-tizenkét éves koruktól a gyerekek már maguk is nyírték a juhot.

Nyírás után színenként elkülönítették a gyapjút. Tartottak ugyanis a fehérek mellett fekete vagy vörösesbarna színű juhokat, hogy ezek szőréből fekete, szürke, illetve barnás árnyalatú fonalat fonhassanak. Ez az elkülönítés a gyapjú feldolgozása során mindvégig megmaradt. Külön áztatták, mosták, tépték,
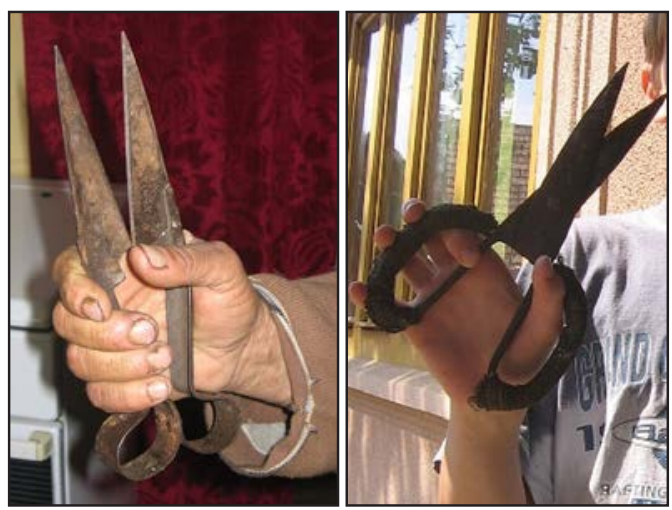

3. kép. Juhnyíró olló (Kerekes Ibolya felvétele) 
fonták a fehér, a fekete és a vörösesbarna színű gyapjút. Külön-külön összecsongolyították, a magukkal hozott zsákokba jó szorosan betűrték a frissen lenyírt gyapjút, és gondosan bekötötték a zsák száját. Egy-egy zsákba öt-hat állat gyapja is belefért. Ezekben a zsákokban tárolták aztán a gyapjút mindaddig, míg el nem érkezett a mosás ideje. Ily módon igyekeztek távol tartani a molyokat, mivel azok nem szeretik, nem eszik a piszkos, ganéjos, zsíros gyapjat. Aki a nyírók közül egy kicsit elmaradt, azt a többiek kisegítették, mert a közös ebéd és a mindenki által várt majálisszerű vigasság csak akkor kezdődhetett, ha minden család befejezte a nyírást (vö. Tagán Galimdsán 1934. 105; 1939. 231233; Timaffy László 1987; Ujváry Béla 1993; Szabadfalvi József 2001. 733.).

Volt társulat, ahol ebédre is ki-ki a maga tarisznyájából ett, másutt készülettel voltak, az otthon már előzőleg megfőzött, szekéren magukkal hozott ételt (leginkább töltelékes káposztát, kalácsot) ették. Több helyütt volt közös főzés, vagyis amíg a többiek nyírtek, addig az adott közösség szokásai szerint meghatározott személyek - leginkább az esztenabíró és a pásztor felesége - az esztenán levágott juhból tokányt főztek a többieknek. Ilyenkor a juhot a pásztor adta a magáéból a közösségnek, cserébe pedig az esztenabíró töltelékes káposztát és kalácsot vitt a pásztor családjának a közösség nevében. Az ebédhez való pálinkáról szintén a bíró gondoskodott. Ebéd után kezdődhetett a vigasság. Előbb csak beszélgettek, énekeltek, majd a párok összekapaszkodtak, és (többnyire) a maguk énekére táncoltak. A férfiak a pásztor szállásának tűzhelyéről kormot szereztek, azzal kergették meg és igyekeztek összekenni az asszonyokat, nagyobb lányokat, akik nagy sikongatás közepette próbáltak menekülni. Válaszul ők is megkergették, vízzel locsolták le a férfiakat (vö. Hajdú Farkas-Zoltán 1993. 99.). A gyerekek ezalatt cekapecceztek (Utolsó pár előre fuss!-t játszottak), fogócskáztak, s különféle dobálós játékokkal szórakoztatták magukat. A havasi vigasság nem tartott túl sokáig, hiszen időben haza kellett érni az állatok ellátására, az esti teendők elvégzésére. Szekerekre ültek tehát, maguk alá tették a gyapjúval teli zsákokat, s indultak vissza a faluba. A hazafelé vezető utat végigénekelték, és a hegyek visszhangozták az énekszót.

Az 1960-as évek elejétől - a kollektivizáláshoz köthetően - megváltozott a nyírás helye és ideje. A juhtartás a szocialista időszakban is megmaradt, a családok viszont nem tudtak már hátramenni a havasra, ezért eltûnt az Orbán-napi közös nyírés és az azt követő ünneplés. A gazdák otthon nyírtak, saját elfoglaltságuktól függően választva meg az időpontot. Napjainkban továbbra is leginkább otthon nyírnak. Februárban, hidegebb esztendőben március első napjaiban kerülnek kézbe a juhnyíró ollók, hogy mire elcsapják a juhokat, már legyen valamennyi sarjúdzott gyapjúk, ne fázzanak meg a havason.

A 20. század végén, az esztenagazdaságok megújulásával a Székelyföldön is feléledt a havasi juhtartás rendjének egyik kiemelkedő mozzanata, a juhlátogatás, esztenalátogatás, vagyis az esztenára felhajtott állatok közösségi felkeresése (vö. Szebeni Géza 1962. 82.). A juhbíró hívására húszan-harmincan szekérrel, traktorral, autókkal mennek föl a közösség esztenájára. A látogatás célja elsősorban a tejbemérés, de aki nem nyírta meg otthon az állatait, az ekkor pótolja. Ilyenkor levágnak egy, a pásztor által felajánlott bárányt, és paprikást főznek belőle. A régi hagyományoknak megfelelően a legtöbb helyen a bárányért cserébe a bíró egy fazékban töltelékes káposztát visz a pásztornak. 


\section{Áztatás, mosás, szárítás}

A csergének szánt gyapjú mosásával mindig megvárták a júniusi, júliusi melegebb idők beköszöntét, amikorra a patak vize meglangyosodott. Egy szép, meleg napon az asszonyok előszedték a zsákokból a gyapjút, átnézték, kiszedegették belőle a nagyobb piszkokat, szénát, szalmát, ganés bogokat. Kisebb darabokra tépték, hogy a mosáskor majd könnyebben bírjanak vele. A ház udvarán langyos vízbe áztatták, néhányszor átdörzsölték, hogy a zsír, piszok hamarabb felpuhuljon, kioldódjon belőle. Volt, aki esővizet fogott reá, mert annak lágy vizében még hamarabb tisztult, puhább lett a gyapjú. Ügyeltek, hogy a víz napközben nehogy reáhúljön, mert akkor a kioldódott zsír visszatapadt a szálakra. Ezért, ha kellett, tűzhelyen melegített vízzel langyosították az áztatóvizet. Ezt aztán nem öntötték ki azonnal, mert ebben a síkos, lúgos, lanolinos lében tisztultak igazán jól az elpiszkolódott gyapjúholmik, posztódolgok, tarisznyák, harisnyák, gyapjúlepedők, takarók, csergék. Hamar híre ment, ha a közelben valaki zsíros gyapjat készült áztatni. Ilyenkor más asszonyok is odakéretőztek, hogy a maguk gyapjúholmiját odavihessék, a zsíros gyapjú vizében kimoshassák. Ennek a víznek aztán már különösebb jelentőséget nem tulajdonítottak, általában a patakba eresztették. Voltak, akik a ganéjdombra vagy a pallagra (a kert füves, kaszálónak hagyott részére) öntötték, mert a jó zsíros víztől a fü is szebben nőtt.

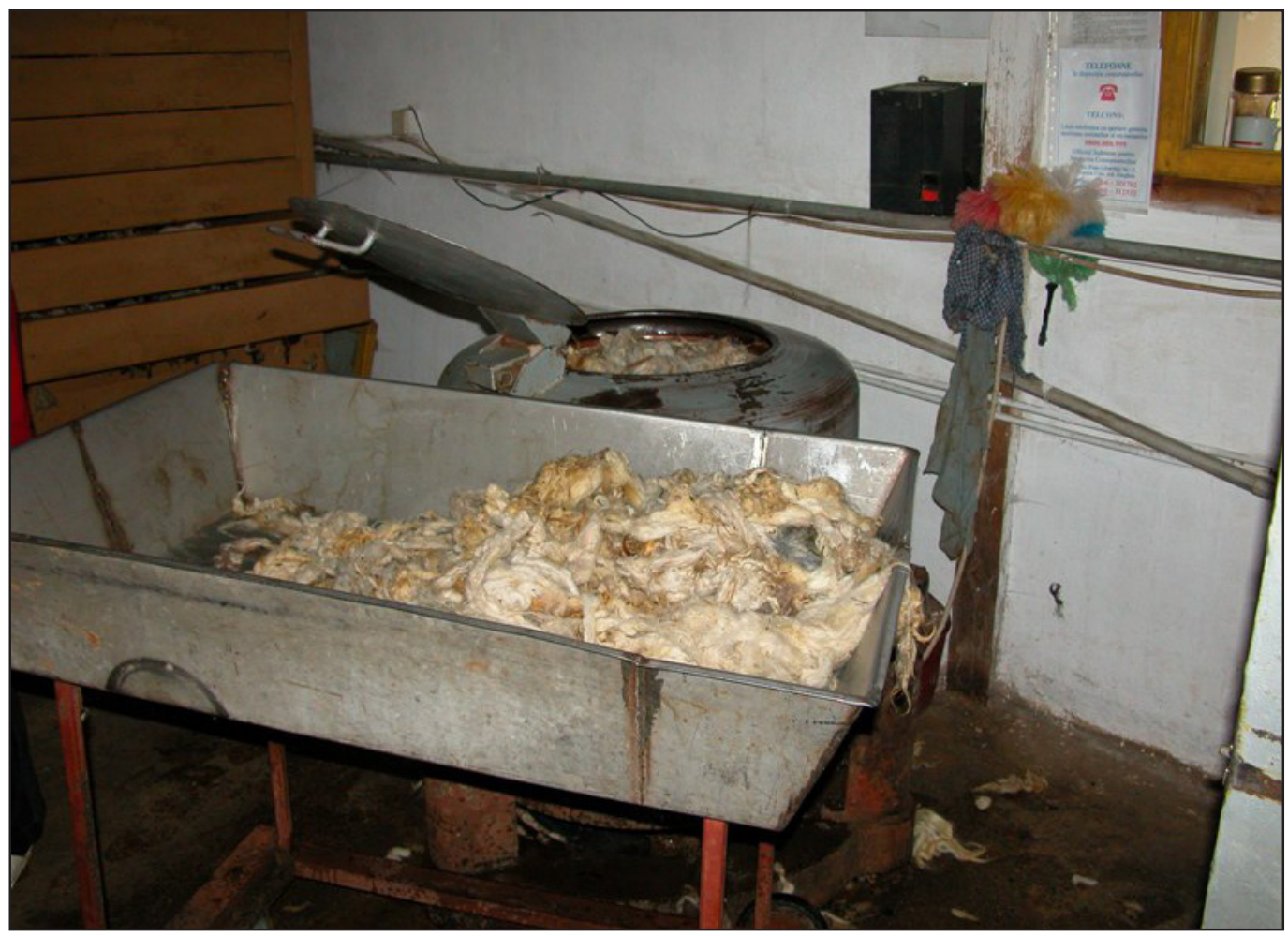

4. kép. Gyapjúmosás a Mózes Gyapjúfeldolgozó Manufaktúra csíkkarcfalvi műhelyében (Kerekes Ibolya felvétele) 
A kiáztatott, átdörzsölt gyapjút még aznap délután, esetleg másnap délelőtt vitték le a patakhoz. Ha sok gyapjú volt, az is előfordult, hogy mosókalákát szerveztek az asszonyok. A vízben kialakított gübóbe beleállították a mosópadot, lábához kosarat kötöttek, hogy abba dobhassák a mosás során leszakadó kisebb darabokat. Sulyokkal jó erősen átkopogtatták, hol lapjával, hol élével ütve a gyapjút. Közbe-közbe kosárba téve belegübbögtették a patak vizébe, újra és újra kiöblítették, kihabarták, megtisztálták. Voltak települések, ahol inkább otthon vagy az utcán lévő vajorokban mosták, tisztálták ki a gyapjút. Ilyenkor a kút, a közös kifolyó vagy forrás vizét használták. Amikor teljesen tiszta víz jött a gyapjúból, akkor csavarták ki alaposan, s vitték vissza a ház udvarára ki-

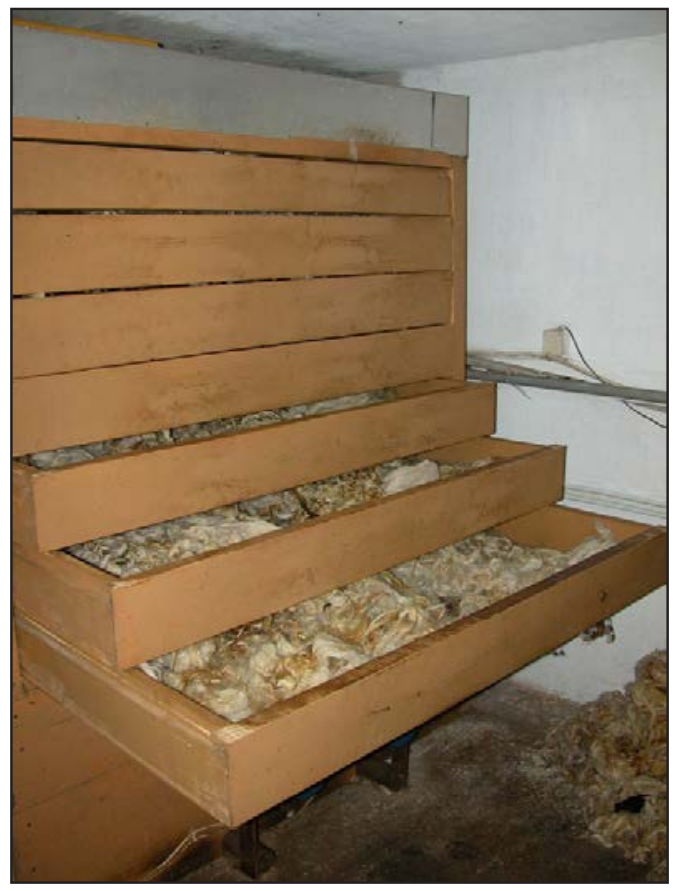

5. kép. Mosott gyapjú tárolása a Mózes Gyapjúfeldolgozó Manufaktúra csíkkarcfalvi múhelyében (Kerekes Ibolya felvétele) teregetni. A nagyobb darabokat kerítésre, a kisebbeket drótra, kifeszített kötélre, felfordított kosárra, tyúkborítóra, ajtóra, deszkára, rácsra, létra fokaira terítették, úgy, hogy a levegő átjárhassa, szárítani tudja a gyapjút. A teljes száradás után színenként elkülönítve kosarakba gyűjtötték s újra zsákokba tették a mosott gyapjút (vö. Benda Judit 2014. 27; Palotay Gertrúd 1937. 273; Szentimrei Judit 1972.157-158; Uő. 1978. 147-148; Szolnoky Lajos 1979).

\section{Tépés, fésülés}

Mosás után hamarosan elkezdték a tépést és a fésülést, mert a tiszta gyapjút a moly is szerette, könnyen rátalált. Amelyik háznál kevesebb gyapjú volt, ott többnyire már nyáron elvégezték ezt a munkafolyamatot. Elsősorban az öregek és a kisebb gyerekek csinálták, akik nem jártak mezei munkára. Kiültek a tornácra vagy egy szélvédett helyre, a zsákból elővették a gyapjút, szétlazították, majd kisebb kupacokat téve maguk mellé finom puhára tépegették. Ha nem volt öreg vagy kicsiny gyermek a háznál, akkor az asszony végezte ezt a munkát is. A színenként különválasztott gyapjút ekkor is külön kezelték. Ha szürke fonalat akartak fonni, akkor fehéret és feketét vegyítettek össze. Akinek volt vörösesbarna gyapjúja, az általában meghagyta azt a maga színében. A tépett gyapjút ölükbe, kötényükbe vagy maguk elé a földre ejtették. Időnként fölállva összegyűjitötték, belerakták az előre odakészített tiszta zsákokba. Az adatközlők emlékei szerint kisgyermekkorukban egy idő után meglehetősen unalmasnak találták ezt a munkafolyamatot. Mégsem hagyták abba, főleg azért, mert édesanyjuk, nagyanyjuk utána cukros törökbúzát (cukros vízben főtt csöves kukoricát) készített nekik, vagy valamilyen más finomsággal, figyelmességgel köszönte meg segítségüket. 
Akinek több gyapjúja volt, az a lerekedés (a juhok őszi hazahajtása) után tépőkalákába hívta magához az ismerősöket, baráti házaspárokat. A megbeszélt estén összegyúlt aszszonyok karimóba ültek, és a középre öntött tépetlen gyapjút elosztották maguk között. A székük mellé húzták vagy egy zsákba gyưrték a nekik jutott részt. Innen szedegettek ki egy-egy maroknyit, s puhára tépve kötényükbe gyűjtötték. Ha tele volt a kötény, akkor középre öntötték a tépett gyapjút. Időnként megálltak, a háziak főtt szemes törökbúzával, piskótával, egy-egy pohár pálinkával kínálták meg a jelenlévőket. A férfiak eközben hátul kártyáztak, beszélgettek, pálinkáztak.
A tépés után rövidesen következett a fésülés. A megkérdezettek jó része még emlékezett arra, hogy egykor otthon kézzel is füsültek. Férfiak, nők, gyerekek egyaránt foglalatoskodtak ezzel. Minden családban volt, aki szívesen végezte ezt a műveletet. Az ehhez használt füsülőt brassói szász mesterek készítették, és vásárokban szerezhették be. Maga az eszköz két különálló darabból állt: egy-egy kb. $15 \times 20 \mathrm{~cm}$-es nyeles deszkalapból, amelyre sürü, finom acélfogazat volt rögzítve. A fogazat szegecsei nem merőlegesen álltak ki az alapból, hanem kissé megdöntve előre, illetve hátra. $\mathrm{Az}$ alsó részt bal kézben tartva, a fogazatba szorítottak egy jó maroknyi gyapjút, és a jobb kézben tartott

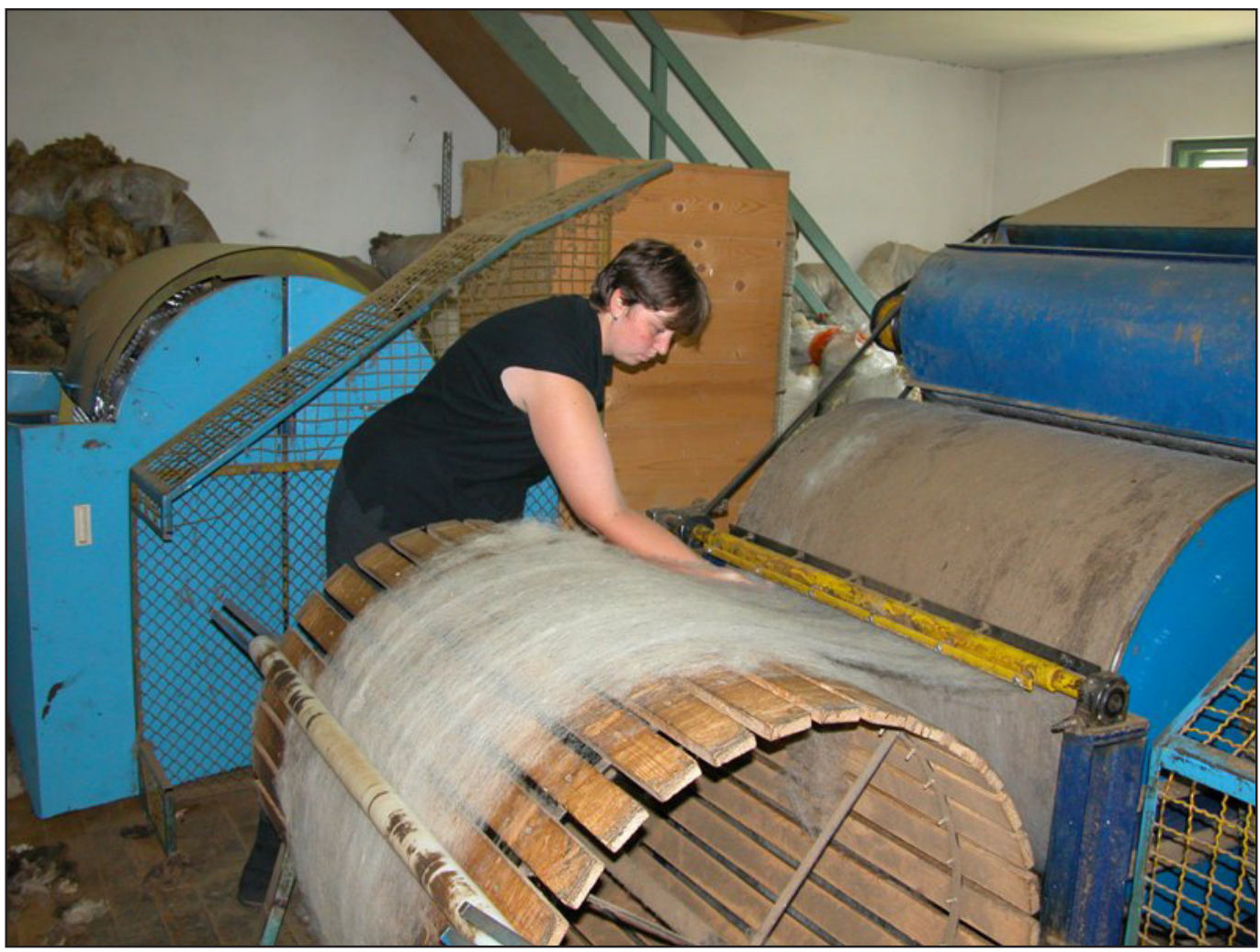

6. kép. Gyapjúfésülő gép a Mózes Gyapjúfeldolgozó Manufaktúra csíkkarcfalvi mühelyében (Kerekes Ibolya felvétele) 


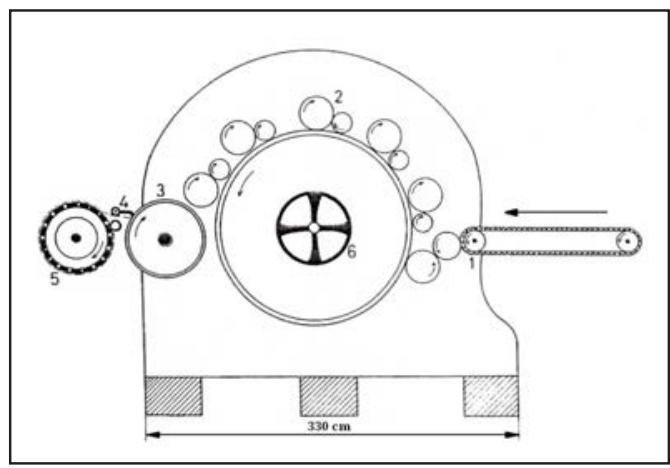

1. ábra. Mosott gyapjú tárolása a Mózes Gyapjúfeldolgozó Manufaktúra csíkkarcfalvi mühelyében (Kerekes Ibolya felvétele)

másik deszkát többször végighúzogatták rajta. Az alsó és felső rész fogazata ellentétes dőlésszögben állt, ezért a gyapjú jól beletapadt, szép szálasra lehetett húzni. Voltak olyanok is, akik a mosópadra kötötték rá a fésülő egyik részét, így azt nem kellett tartani. A másikkal húzogatták, fésülték a gyapjút (Palotay Gertrúd 1937. 273.).

Mivel időt, türelmet igénylő, haladatlan, sok szállongó szösszel járó munka volt, a gyapjúfeldolgozásnak ez a fázisa sok helyen kikerült a házból. Erre szakosodott, vízierővel vagy később villanymotorral hajtott füsülóbe vitték a gyapjút - még ha fizetni is kellett érte. A gépi fésülés jóval gyorsabban ment (egy óra alatt kb. 8-10 kg gyapjút tudtak földolgozni), s az otthon, kézzel füsültnél finomabb, lazább szerkezetű, egyenletes minőséget eredményezett.

A fésülőműhelyben az előkészített, mosott gyapjút előbb a tépetóbe, gyapjútépóbe tették. A kézi fésülőhöz hasonlóan ez is két fó részből állt, de ez a két rész egyetlen, lábakon álló, rögzített szerkezetet alkotott. Egy csónakszerűen, enyhe hajlással készített alsó elemből és egy - ebbe a csónakszerű, alsó hajlásba illeszkedő - felső elemből állt. Az alsó elemet tartó keretbe jobb és bal oldalról egy-

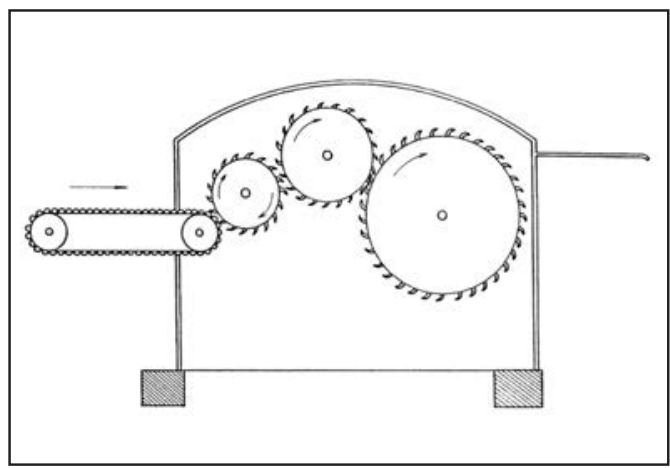

2. ábra. Gyapjútépő gép müködési vázlatrajza. A rajz a kibédi Szilveszter család gépéról készült. In: Márton Béla 1995. 124.

egy függőleges állványt is rögzítettek, amelynek a felső végén egy-egy mély vájat volt. E vájatok tartottak meg egy keresztbe fektetett, négyszögletesre faragott, erős rudat. Ehhez a vájatokban szabadon elforduló rúdhoz volt hozzáerősítve a tépető csónakszerű alsó részébe illeszkedő felső elem. Az állvány tartotta keresztrúd mint egy vízszintes tengely működött. Segítségével a felső elem el tudott mozdulni, előre- és hátrairányuló lengőmozgást tudott végezni a rögzített alsó elem fölött. Mindkét elemrészbe (a kézi fésűhöz hasonlóan) sűrűn egymás mellé ellentétesen hajlított, farkasfogszerűen elvékonyodó acéltüskéket helyeztek. A felső rész mozgatásával ez a fogazat fellazította, puhította a tépetőbe helyezett szálakat. A kézi füsülóhöz hasonló elven működött tehát ez a szerkezet is, ám mivel nagyobb felülete volt, hamarabb kész lett vele a munka. A tépetôt alapvetően kézi vagy vízi erővel mozgatták, de a 20. századra ez a szerkezet sem kerülte el a gépesítést.

A tépetés után vitték át a gyapjút a patakvízzel vagy motorral hajtott fésülőgép asztalára. Ez a gép már gyárban készült, bonyolult, több egymásra helyezett hengerből álló vasszerkezet volt. Fésülő, puhító és simító 


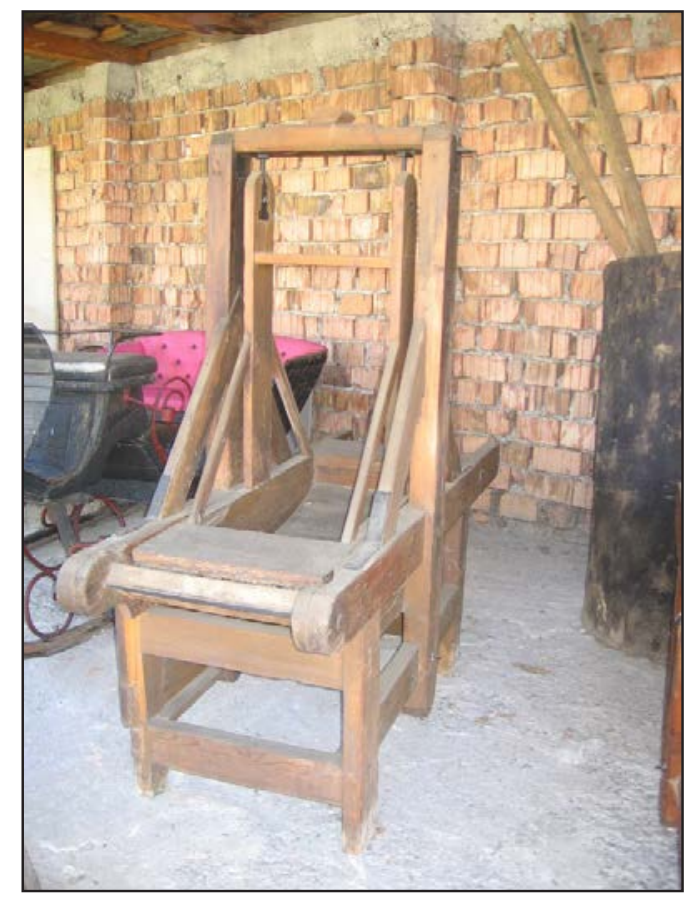

7. kép. Gyapjútépő a gyergyószentmiklósi Tarisnyás Márton Múzeum udvarán (Kerekes Ibolya felvétele)

hengerek sora. A gép elejét képező asztalról adagolták a hengerek közé a fellazított, tépett gyapjút. Az elöl lévő hengereken még nagyobb tüskék voltak, amelyek vékony szálakra szedték szét a tépett gyapjút. Az egyre kisebb tüskéjű hengerek egyre finomították, a simító hengerek puhították, rendezték a szálakat. Az utolsó fésűsor leválasztotta a hengersorról és a feltekerődobra irányította a gyapjút. A hengereket borító, hengerenként egyre finomodó apró tüskék tehát lágy, egyenletes paplanná kártolták (Gáspár Gyula 1939. 660; Márton Béla 1995. 122-125.). A fésülőről lekerült „gyapjúpaplant" egyes helyeken a gép kezelője végül még guzsalynyi egységekbe, félkilós, kilós bundákba is osztotta, feltekerte, s így tette vissza az otthonról hozott zsákokba.
A gép tulajdonosa a gyapjú súlya alapján határozta meg a munkadíjat, a fésülés árát. Ezt elsődlegesen pénzben kellett leróni, de egy részét gyapjúval is meg lehetett váltani. Általában a gyapjú súlyának 10-20 százalékát hagyták ott vámba. A fésülő tulajdonosa ezt a gyapjút legtöbbször eladta olyanoknak, akiknek a szükségesnél kevesebb gyapjújuk volt (vö. Márton Béla 1995). Volt olyan füsülős is, aki a vámba hagyott gyapjú jó részét kötőfonalnak dolgozta fel, és a környékbeli asszonyok tőle vásárolták a szvetternek való fonalat.

Az 1960-as évek elejétől kezdődően lassan eltűntek a családi vállalkozásban működtetett kisebb fésülők, szerepüket a háziipari szövetkezetek fésülőgépei vették át. (Bár azért, ha csak mutatóba is, de a szocializmus évtizedeiben is maradt egy-két, magánháznál működtetett fésülő.) Az 1989-ben bekövetkezett politikai változások a gazdaság átalakulását is magukkal hozták. Ennek egyik következménye volt, hogy Erdély-szerte fölszámolták a háziipari szövetkezeteket, felszerelésüket - jó esetben - magánvállalkozók vásárolták meg. Közülük néhányan újra elkezdték múködtetni a régi fésülőgépeket, így ma is vannak olyanok, akik vállalják az otthonról hozott gyapjú fésülését.

\section{Fonás}

A fésülés után igyekeztek minél előbb megfonni a gyapjút. Amíg a kendert és a festékesnek, rakottasnak félretett gyapjút többnyire külön erre a célra szerveződött fonókban, hosszú őszi, téli estéken dolgozták fel, addig a cserge fonala főleg nyáron készült, és otthon, maguknak fonták. Amint a nyári munkák közben egy kis időt tudtak lopni reá, vagy épp esős napok köszöntöttek be, azonnal elővették, s fontak, durgáltak (vö. Hajdú Farkas-Zoltán 1993. 92.). 
A fonás két ősi kelléke az orsó és a guzsaly. Az orsó keményfából készült, 40-50 cm hosszú, mindkét végén hegyes, tetejétől kezdődően fokozatosan vastagodó, alsó részén hasasra esztergált egyszerű eszköz. A Székelyföldön használt guzsaly elterjedt típusa majd két méter hosszú, általában nyolcszögletűre faragott rúd, amelyet egy talpba illesztettek bele. Az egyszerűbb talp egy akkora deszkacsík, amelyre a fonást végző kényelmesen rátehette a lábát, hogy a guzsalyrúd fonás közben biztosan álljon. Ügyes kezű férjek, apák, legények, utóbb helybeli asztalosmesterek készítették. A guzsalyrudat nemegyszer meg is cifrázták, volt, aki színesre (pirosra, zöldre) festette. Előfordult, hogy a talpat is díszítették: kerekre, szív alakúra, vagy herelapi (lóhere) formájúra faragták, aljába pedig 4-6, alig néhány centis lábacskát tettek (bővebben: Kós Károly 1980; Nécsey István 1900; Domokos Pál Péter 1930; Gönyey Sándor 1943; Nagy Jenő 1947).

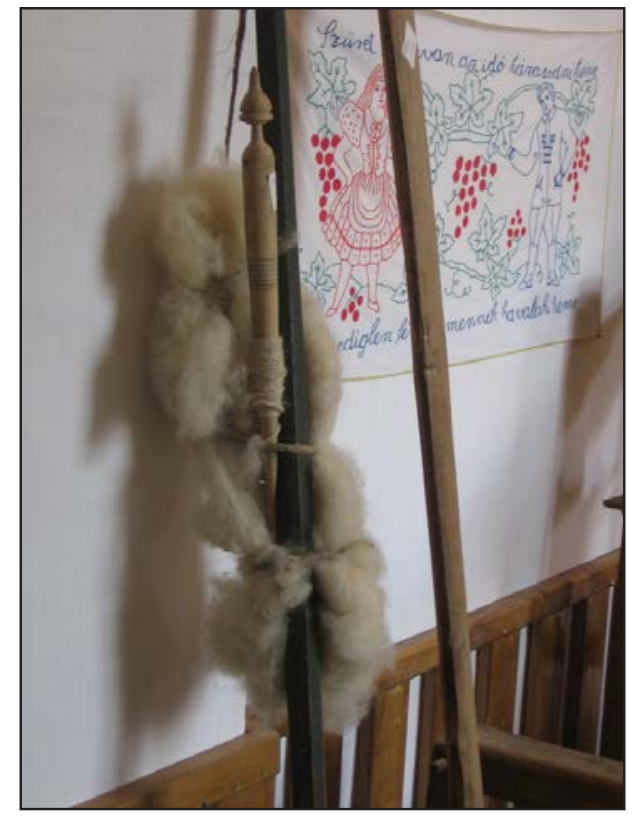

8. kép. Guzsalyra kötött gyapjú és orsó (Kerekes Ibolya felvétele)
A fonó kisujjnyi széles pamutszalaggal, kenderből sirített vastagabb fonallal erősítette fel a gyapjút a guzsalyrúdra. Ezután székre ülve, guzsalyát maga mellé téve vagy két térde közé szorítva, lábát a guzsalytalpra téve elkezdte a fonást. A gyapjúból óvatosan húzta ki a kezdőszálakat, s ujjai között sodorva jó félméternyi fonalat készített. A fonal végét az orsóra kötötte, majd ettől kezdve bal kezének mutató-, középső- és nagyujjával folyamatosan húzta ki a gyapjúszálakat, jobb kezével pedig az orsót pörgette, hogy arra tekeredjen a fonal. Amikor úgy érezte, hogy megvan egy duvaszka - azaz tele lett az orsó, nem tudta már ujjaival sem tartani, sem pörgetni -, akkor rövid időre abbahagyta a fonást. Fölállt, fölmatollálta a fonalat, különben a lazán megsodort fonal az orsóról lehúzva azonnal szaladt, összegabalyodott volna. Ha kész volt a matollálással, akkor ült le ismét a guzsaly mellé, s folytatta tovább a fonást.

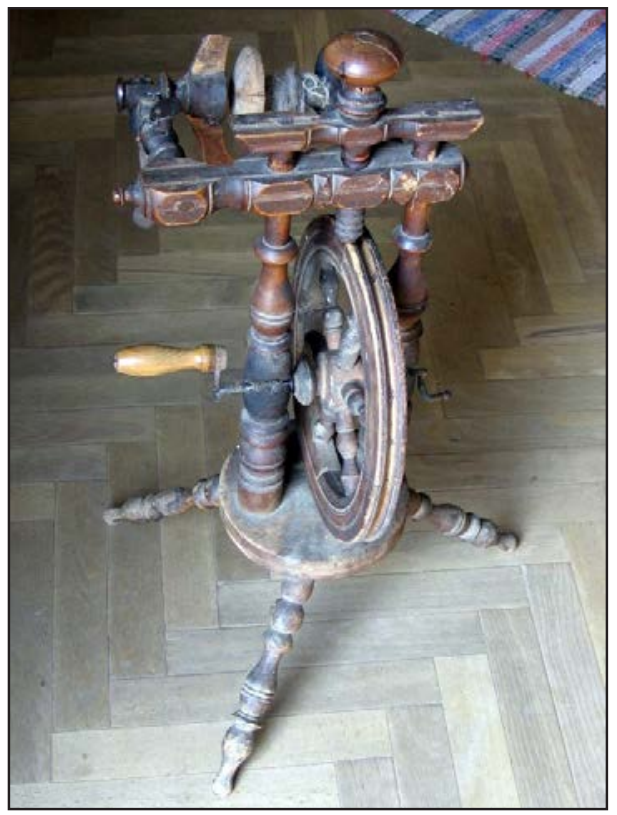

9. kép. Fonókerék, rokka (Kerekes Ibolya felvétele) 
A 20. század közepén terjedt el a Csíki-medence falvaiban a fonókerék (rokka) használata. Helybéli asztalosmesterek készítették megrendelésre. A szerkezet függőlegesen álló kerekét egy fogantyú segítségével a fonó hajtotta. Ez hozta mozgásba a vízszintes vaspálcára illesztett vékony, csőszerű orsót, amelyre föltekeredett a guzsalyról eresztett gyapjúszál.

Egy csergére kb. 6-8 kg fésült gyapjút számítottak. Ebből kétféle vastagságú fonalat készítettek. Hüvelykujjnyira húzták, s alig sodorták a leverőszálat, ontokot (vetüléket). Valamivel vékonyabbra durgálták, jobban sirítették (sodorták) a mellyéknek (felvetőszálnak) szánt fonalat. Volt olyan asszony, aki a vetüléket talpas guzsallyal, a felvetőszálat pedig fonókerékkel fonta. Az utóbbival ugyanis erősebb fonalat lehetett sodorni. Nyugodalmas, esős napon akár egy csergére valót is meg tudtak egyszerre fonni. Ilyen alkalom azonban gyéren adódott. Jobbára néhány nap alatt, kicsidenként fonták meg a csergének való fonalat.

\section{A szövés előkészületei}

Egyenesen az orsóról matollálták föl tehát a fonalat. Ennek eszköze egy T-alakú, fejes vonalzóra emlékeztető, alul villában végződő kézi matolla. Hossza általában 1,75-2 m, szélessége 8-10 cm. Tetején keresztben egy 40-45 cm-es, kissé elvékonyodó fejben végződött, alsó villája 5-7 cm magas. Az eszközt matolláláskor keresztbe fektették az asztalon, úgy, hogy mindkét vége kissé lelógjon, szabadon maradjon. A fonal végét az alsó villa egyik ágára kötötték, majd a fejrészen lévő T-nek felváltva hol az egyik, hol a másik oldalát kerülték meg a fonallal, $\mathrm{s}$ tértek vissza az alsó, villás véghez. Ha az orsóról elfogyott a fonal, folytatták a durgálást. A matollán időnként megolvasták a feltekert szálakat, hogy megfelelő mennyiségű fonalat készítsenek elő a szövéshez. 3 szálat mondtak 1 igének, 20 igét (60 szálat) 1 zserébnek. ${ }^{3}$ Ha 3-4 zserébet (180-240 szálat) fölmatolláltak, akkor a villánál egy kis darab fonallal összekötötték, matollástul levitték a patakhoz, esetleg egy előre odakészített, vízzel teli cseberhez, belemártották, s a matollát villájára állítva hagyták megszáradni. Az így előkészített fonalat előbb a T-alakú fejrész két oldaláról, majd az alsó villáról lehúzva már sokkal könnyebben tudták kezelni, nem bedrett, nem sodródott össze.

A matolláról leemelt fonalat legtöbbször festetlenül hagyták, a maga természetes színében használták. Akik viszont a fehér, szürke, vörösesbarna szín mellett más árnyalatokat is szerettek volna beledolgozni a csergébe, azok festőanyagokat használtak. A bolti festékek elterjedés előtt ezek különféle növényi részekből készültek. A fekete színt például cserefahéjból/egerhéjból tudták előállítani. Egy idős adatközlő emlékei szerint az egerfa kérgét nyáron - „amikor a mézga ott van a kéreg alatt" - meghántották, megszárították. Felhasználás előtt kézzel törték apróbb darabokra, majd kis fabottal megütögették, megtörték. Boltban vásárolt gálickővel keverték össze, vizet öntöttek rá, és egy nagyobb fazékban fölforralták. Eközben egy üstre botokat tettek keresztbe, ezekre bojtokat, hajlát (fenyőágakat) fektettek. A sűrűn egymásra helyezett ágak túlevelei szűrték meg a festőlevet. Ebben a lében áztatták aztán a festésre szánt fonalat. Kihűlés után hideg vízben tisztálták meg. Hasonlóképpen jártak el a dióhéjjal, amelyből barna színt nyerhettek (Vö. Bartha Károly, N. 1937. 19-22; Palotay Gertrúd 1937; Szentimrei Judit 1972. 168-171; Miklóssy V. Vilmos 1978. 91-100.). 
A 20. század első felétől terjedtek el a boltban vásárolt, az asszonyok által pilifuxiaként, vagy egyszerűen csak fuxiaként emlegetett bázikus festékek, amelyeket a sokféle szín könnyű előállítása és jó színtartósága tett közkedveltté. Főként a festékesek fonalának előkészítésénél használták, de utóbb már a csergeszövők is alkalmazták néhány színét. A II. világháború után egy másik, Galos, illetve Gallus néven említett textilfestéket tudtak beszerezni. Ezt használták, ha a juhok fehér, fekete, vörösesbarna színű gyapjának öszszevegyítésén túl valamilyen más színnel is szerették volna díszíteni a csergét. ${ }^{4}$

A matollálás, és ha kellett, a festés után az összekötött szálakat kézzel összefogták, $\mathrm{s}$ átemelték a tekerőlevelre. Ennek felső része két, 1-1 méter hosszú, tenyérnyi széles, keresztben összeilleszthető deszkából, ún. levelekből állott. A közepükön lévő lyukba helyezett vékony, esetenként egyszerű faragással díszített pálca segítségével lehetett egy kereszt alakú talpban végződő rúdhoz rögzíteni. A felső kereszt deszkáinak végére készítője két-három furatot is tett. A megfelelő furatba illesztett pálcákkal akkora méretet állíthattak be maguknak az asszonyok, amekkora a matolláról lekerült fonalköteget feszesen tartotta. Mivel csak a középső, vékony pálca tartotta a talpazathoz a felső keresztet, e tengely körül könnyen el tudott fordulni, s kényelmesen lehetett róla letekerni, gombolyítani a fonalat. Ha leveröfonalnak (vetüléknek) való szálakat tettek a tekerőlevelre, akkor azt kézzel tekerték föl több, egyenként 35-50 cm hosszúságú, 6-8 cm széles, két végén ívesen bevágott, vékony falapra, csépre. A mellyéknek való fonalat csöllőkerék segítségével a vetélők lyukas közepűre esztergált pálcáira csöllötték, tekerték fel (Szolnoky Lajos 1991. 366-367; Kardalus János 2000. 221.).

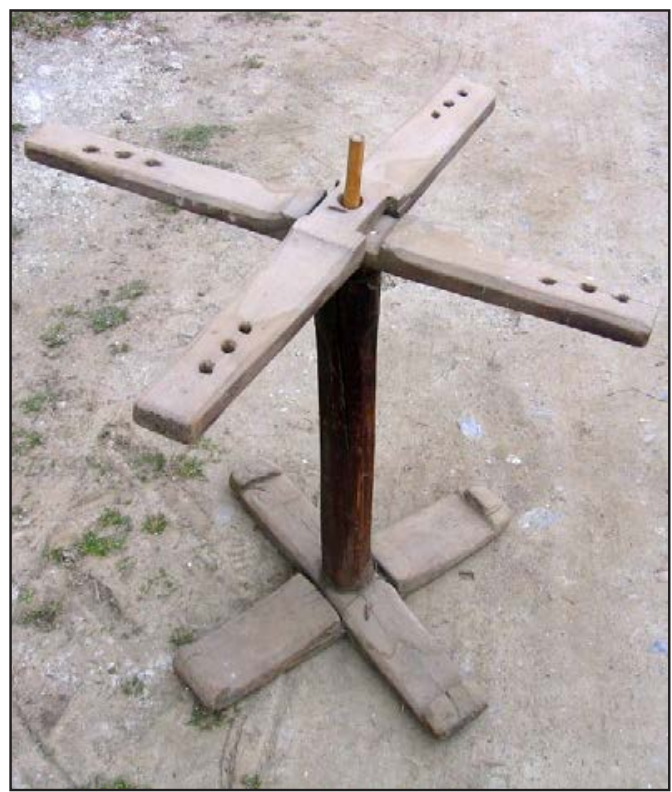

10. kép. Tekerőlevel (Kerekes Ibolya felvétele)

Ezután vetőfára tekerték föl a szálat, ami már a szövőszékre való fölvetést készítette elő. Attól függően, hogy milyen hosszú csergét akartak szőni, a hossz kétszeresét vágták le először a gombolyagról. A levágott szálat a vetőfa alsó részéhez kötötték, majd spirálisan tekerték föl az oldalsó léceken. Ez a szál volt a mérték, ehhez képest számlálták a szükséges szálmennyiséget. ${ }^{5}$

A fonalak előkészítése után következett a szövőszékre való fölvetés. Szövéshez ugyanazt a szövőszéket (osztovátát) használták, mint a kender- és gyapjúszőttesekhez, csak a bordában volt különbség. A csergéhez való borda furatai ugyanis gyérebben voltak, és akkorára készítették, hogy azokon a mellyék vastag szálai átférjenek. (A felvetés mozzanatairól részletesen: Csókos Varga Györgyi 1992. 107-113; 1998. 112-126; Márton Béla 1993. 22-23; vö. Tagán Galimdzsán 1935. 85-86.).

Néhányan próbálkoztak azzal, hogy a rakottashoz hasonlóan a csergéhez is az erő- 


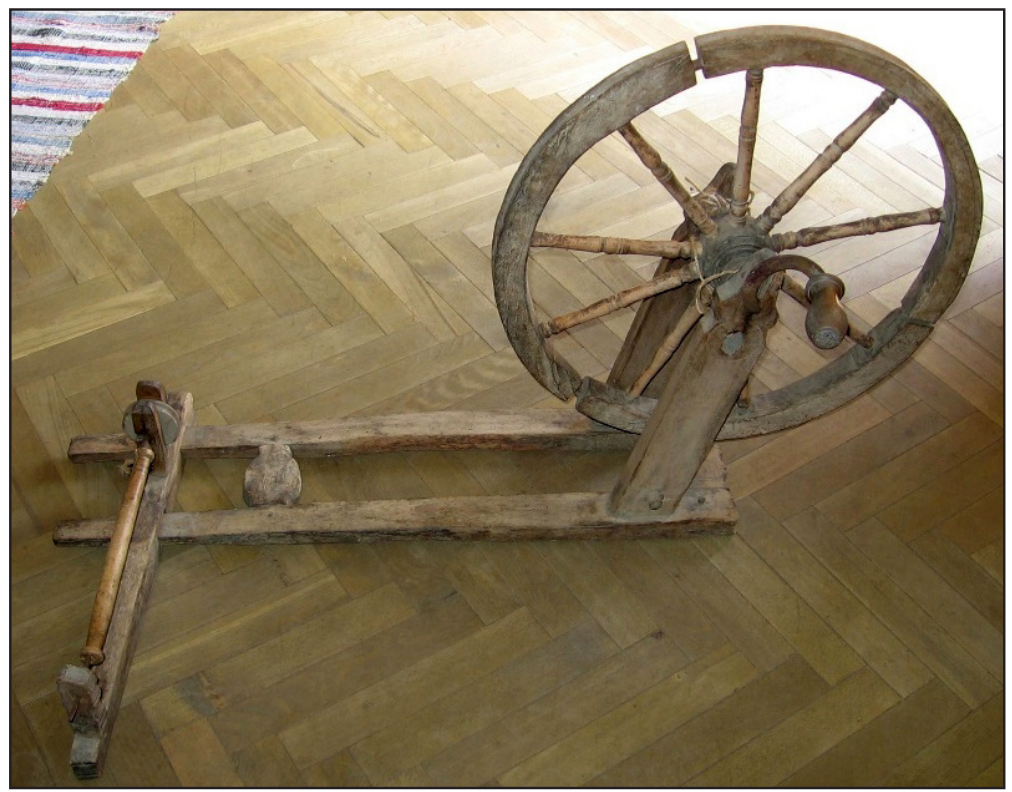

11. kép. Csöllőkerék, durgálókerék (Kerekes Ibolya felvétele)

sebbnek tartott pamutfonallal vessenek föl. Az újító próbálkozás azonban nem mindenütt vált be. Az így készült szövet ugyanis már az osztovátáról levágva is gyưrüsödött, hullámosodott, főképp pedig a ványolás után vált egyenetlenné a felülete, mert a vízre és a mechanikai ráhatásra eltérően reagált a kétféle alapanyag. A cserge felvetőszála - az újító kísérletek sikertelensége miatt - általánosan a gyapjú maradt a Székelyföldön. Az 1950-1970-es években azonban - amikor a kötelező leadások miatt időnként meglehetősen gyapjúszúkében voltak - előfordult, hogy a mellyék gyapjúszálai közé minden harmadik vagy negyedik szálat kenderből vetették.

\section{Szövés}

A hosszadalmas előkészületek után a szövés már gyorsan ment, mert a vastag fonallal szaporán haladtak. A csíki asszonyok, házasságra készülő leányok általában kétnyüstös osztovátán, kettős lábítóval szőtték a csergét. ${ }^{6}$
Jó esetben egy, kevésbé jó esetben két nap alatt készültek el vele. Leggyakrabban egyszínű fehér vagy szürke csergét készítettek. Ezzel hamar elkészültek, hiszen a felvetőszálak között csak a csépre tekert leverőszálat kellett átvezetni hol az egyik, hol a másik oldalról, és a bordával ráverni. Az osztovátán általában 60-100 cm széles gyapjúszövetet tudtak szőni. Ettől függően két, három vagy négy ilyen szél (szövetcsík) összeöltésével állították elő a megfelelő méretű - általában 3-3,5 méter hosszú, 1,6-2,4 méter széles szốtteményt. Ha cifrázni is akarták, akkor a szürke, illetve fehér alapszínbe csíkokat, négyzetet, ritkábban rombuszt szőttek. Az alcsíkiak fehér, szürke, fekete, piros, a felcsíkiak ezenkívül még kék, sárga, esetleg zöld színt használtak díszítésre. ${ }^{7}$ Azzal már a szövéskor számoltak, hogy ványoláskor felére, harmadára apad a cserge. A kisebb csíkokhoz ezért legalább 5-10 cm-t, a nagyobbakhoz legalább 30-60 cm-t szőttek. A mintával díszített csergék szövése több figyelmet igé- 


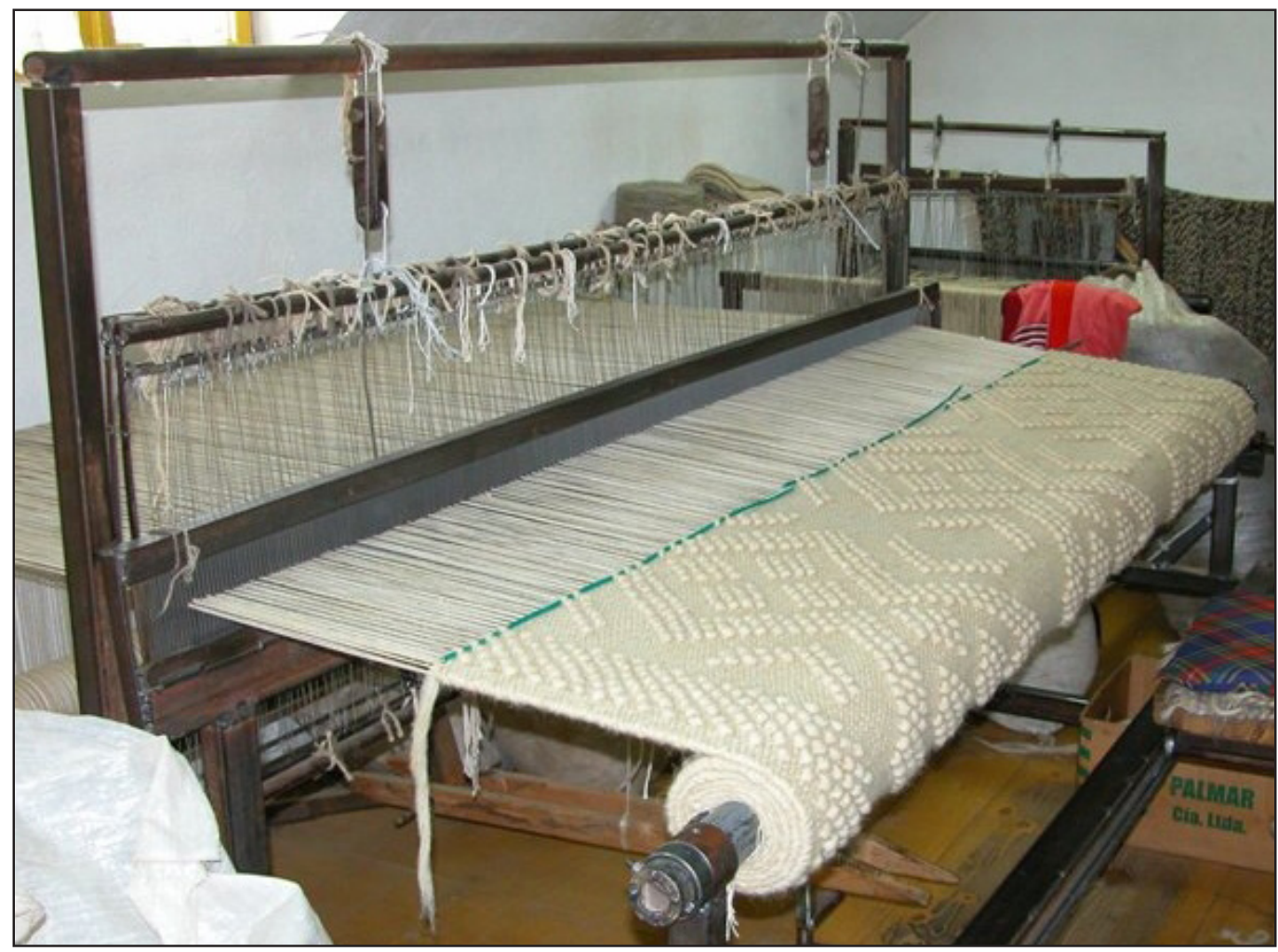

12. kép. A csíkkarcfalvi Mózes Gyapjúfeldolgozó Manufaktúra szövőszéke (Kerekes Ibolya felvétele)

nyelt, mert pontosan kellett számolni ahhoz, hogy majdan a takaró összeállításakor, a szélek összeöltésénél a minták találkozzanak, illetve a kívánt ritmust adják ki. Ha megvolt a megfelelő hosszúság, a gyapjúszövetet levágták a szövőszékről. Az egymás melletti felvetőszálakat jó erősen összekötötték, és visszafüzték, vagy rojtnak hagyták meg (vö. N. Bartha Károly 1932. 19-23.).

Az egyes csíkok szélein, ahol a csépen vezetett fonal átfordul egyik sorból a másikba, egy kicsiny rés marad. Egy arasznyi hosszú, vastag tűbe a mellyékből maradt fonalat füztek, s ezekbe a szélső kis résekbe szúrva a tűt egyszerúen összevarrták a két szélt. Az egyszínűre szőtt csergék összeöltése gyorsan ment. A csíkozottaknál vagy a cifrázottnál kellett figyelni arra, hogy a megfelelő sorok a megfelelő helyen találkozzanak, s így szépen jöjjön ki a minta.

Júniusban, augusztusban a legtöbben készen voltak a cserge szövésével és összeállításával. Mivel ezután egy időre kikerült a házból, jegyet varrtak bele (Kardalus János 1977). Ez legtöbbször a cserge egyik sarkára varrott, a családnév kezdőbetủjét formázó textildarab volt. Ezután következhetett a ványolás.

\section{Ványolás}

A csergekészítés munkafolyamatának ezen a pontján a cserge egyébként is vastag szövete még inkább összesűrűsödött, tömörült, lomot eresztett, erős és tartós lett.

A ványolás „szezonja" május végétől szeptemberig tartott. A nap melegétől a patak 
vize is meglangyosodott, és ebben a lenge nyári vízben tudott igazán jól ványolódni a cserge. Éppen ezért a legtöbben a nyári melegben, júliustól augusztus végéig (csipkerózsanyílástól Szent Istvánig) vitték, küldték ványoltatni a csergét.

Egykor sok székelyföldi település határában ott voltak a ványolókádak. A tiszta vizü, gyors folyású hegyi patakok vize mellé több helyen is vízimalmok települtek. E malmok a víz erejét - a gabonaőrlés, gyapjúfésülés mellett - ványolásra is felhasználták (Gáspár Gyula 1939. 661-663; Ozsváth Gábor Dániel 2011. 137-141; 2014). A malom melletti mederbe 2-3 méter átmérőjű, 1,5-2 méter magas, kerek, alul keskeny, fölfelé bővülő csonka kúp vagy tölcsér alakú fakádat, ványolókádat helyeztek, amelyet a meder köveivel körbe is raktak, hogy ne tudjon elmozdulni. Dongáit korábban füzvesszővel fonták körül, utóbb fa- és vasabronccsal fogták össze. Mivel tartósan, folyamatosan mozgó, nagy víztömeget kellett megtartaniuk, erős támasztólábakkal is megerősítették, alátámasztották az abroncsot.

A patak vizét fából készített vályúval (lajjal) terelték a ványolókádhoz. A laj készítésénél figyeltek arra, hogy a víz kb. 1, 2, 2,5 méterrel magasabbról induljon a kád felé, és fölötte, kb. 30-50 centiméterrel beljebb érjen véget. Ezzel a szintkülönbséggel és a viszonylag keskeny vályúval biztosították, hogy a víz nagy sebességgel zúduljon a kádba. A laj beállításakor arra is figyeltek, hogy a lezúduló víz úgy érkezzen a kádba, hogy lehetőleg az óra járásával ellentétes irányú, örvénylő mozgást alakítson ki. Ez az örvénylő mozgás ragadta magával újra és újra a csergét.

A kádba eresztett cserge először vizet szívott magába, és merülni kezdett a kád alja felé. Mivel a patak vize folyamatosan és felülről érkezett nagy sebességgel a kádba, így nemcsak a laj beállításának köszönhető ol- dalirányú örvénylés, hanem egy fentről lefelé és lentről felfelé tartó, folytonos keringés is kialakult a kád belsejében. Ez a lentről felfelé irányuló mozgás újra és újra felszínre vetette a csergét. Az pedig a felszínre érve megint átvette az oldalirányú, keringő mozgást, majd az örvény holtterébe kerülve a nagyméretú, vízzel átitatott gyapjút ismét lefelé húzta súlya. A felülről érkező és a szintkülönbség hatására nagy sebességgel lezúduló víznek akkora ereje volt, hogy a kád aljára került víz szinte azonnal elkezdett nagy erővel fölfelé sodródni. Ez a fölfelé irányuló vízmozgás ismét felszínre vetette a csergét, amely fent újból belekerült az oldalirányú keringésbe. Lemerülés, felszínre vetődés és oldalirányú forgás. Ezzel a folyamatos mozgással teltek az órák, napok. Éppen azért kellett a kádnak megfelelő formájúnak és méretűnek lennie,

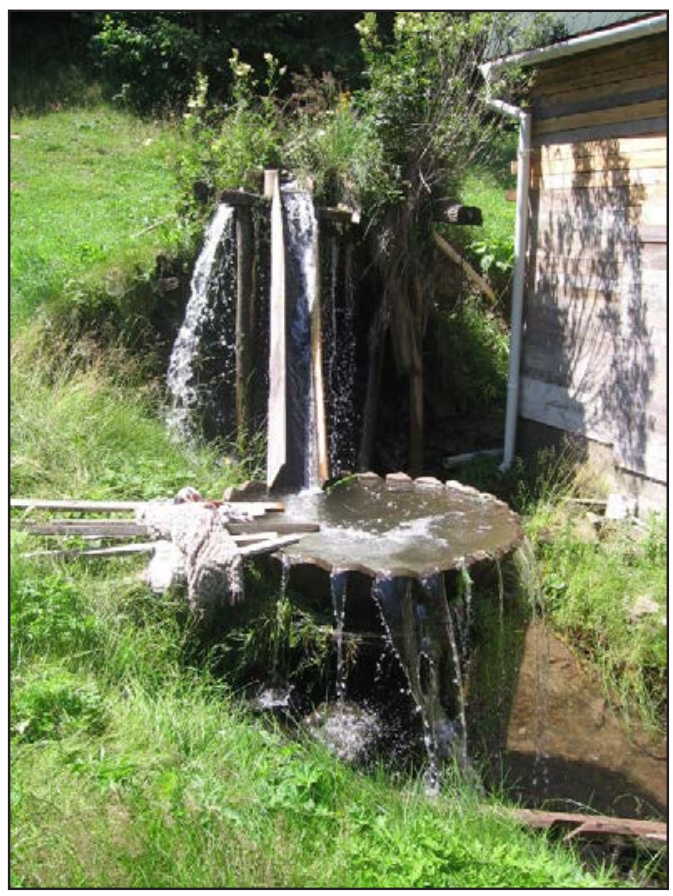

13. kép. Ványoló Székelyvarságon (Kerekes Ibolya felvétele) 
hogy a cserge elférjen benne, és legyen helye a folyamatos forgó, örvénylő mozgásra. E mozgás során tömörültek össze a gyapjúszálak, vált erőssé és lomossá a cserge anyaga.

A kádban lévő víz mennyiségét és a fölösleg elvezetését a dongák felső végének kialakításával, valamint a dongákba fúrt lyukakkal tudták szabályozni. A dongák felső végének kialakításában három típussal találkozhatunk. Az egyiknél a dongák vége egyenes, a szélektől 40,50 vagy 60 centiméterre lyuksor található. A másiknál a végek lekerekítettek, a felső végek alatt körben, azonos magasságban ugyancsak megtalálható a lyuksor. A harmadik típus dongáinak végét fent szögletesre faragták, jobb és bal oldalon pedig - a tetejétól kb. 40-50 centiméterre - háromszög alakban bevágták. A dongák összeillesztése után ennél a típusnál is egy szögletes lyuksor alakult ki a felső széltől egyenletes magasságban. A felső lyuksor biztosította a fölösleges vízmennyiség elvezetését, a dongák végének gömbölyű vagy csúcsos kialakítása pedig azt akadályozta meg, hogy a nagy sebességgel kavargó, örvénylő vízzel a cserge átbukjon a ványolókád peremén. Előfordult, hogy néhány dongán lejjebb is fúrtak egy-egy lyukat. Ezek bedugásával, illetve megnyitásával lehetőség nyílt a kád vízmagasságának szabályozására.

Legalább egy teljes napon keresztül mozgott, kavargott a vízben a cserge, de ha mód volt rá két-három napot is hagyták. Időnként a ványolós is odament a kádhoz, egy hosszú rúddal, horgasbottal belenyúlt, átforgatta a szőtteményeket. Volt, hogy ki is vette a kádból, hogy megnézze, hol tart a cserge tömörülése, lomosodása. Éppen ezért volt, ahol a kád mellé egy asztalt is beállítottak, ide emelhették ki a csergét. Amikor már késznek ítélték, kivették a kádból. Mivel maga a cserge nagyméretű volt, ráadásul vizesen még a súlya is megsokszorozódott, a kádból való kiemelése nehéz munkát jelentett. Ha csak lehetett, nem is egyedül végezte a ványolós, hanem segítséget hívott. Szakaszosan húzták ki, és hagytak egy szusszanásnyi időt, hogy a kihúzott részből kicsoroghasson a víz. Ha a kád mellé volt asztal állítva, akkor oda emelték ki a csergét, ha nem, akkor a ványoló melletti füves területre vitték, és terítették ki, ahol kifolyhatott belőle a víz nagy része. Kicsiny idô múltán külön erre a célra használt, lehetőleg napos, szellős helyen álló szárítóállványra terítették át. Ez az állvány erős lábakból és egy szintén erős, rendszerint 5-8 m hosszú, 10-12 cm vastag, hengeresre faragott, sima felületű keresztrúdból állt. Az állvány magassága akkora volt, hogy a félbehajtott cserge ne érjen földet, ki tudjon folyni belőle a víz. A rúd azért volt olyan hosszú és erős, hogy egymás mellett akár két-három cserge is száradni tudjon rajta. A vastagsága pedig azért volt fontos, hogy a rétegek között a levegő tudjon járni, mihamarabb meg tudjon száradni a cserge (Gáspár Gyula 1939. 661-663; Nagy Mari Vidák István 2014).

Száradás után még átfésülték, mert a vízben mozogva a szálak megbolyhosodtak, lomot eresztettek. A ványolt cserge megapadt, legalább harmadával lett kisebb az eredetileg szőtt és több szélből összeöltött mérethez képest, de vastagsága hozzávetőlegesen megduplázódott. A tömörülés hatására a szélek közötti összeöltés sem látszott már.

Létesültek kifejezetten a posztónak szánt gyapjúszövetekkel iparszerűen foglalkozó, egész évben múködő ványoló- vagy kallómalmok is. Itt is vállaltak csergeványolást. Ezekben ütőbotokkal és melegített vízzel segítették a szálak tömörülését. Mivel katlanokban melegített vizet használtak, egész évben tudtak ványolni. Múködésükhöz itt is a patakok vize biztosította az energiát. A víz ereje egy 


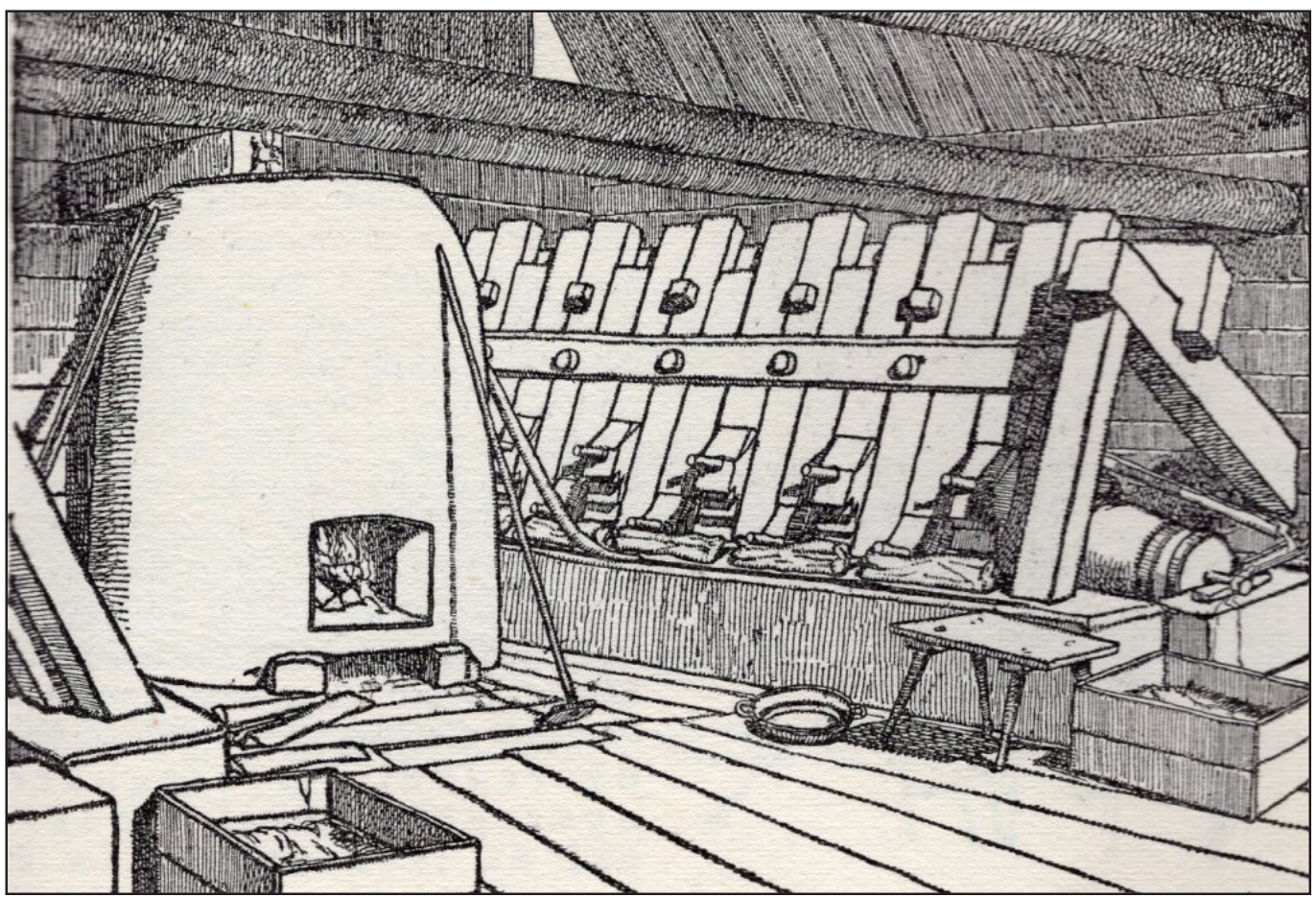

3. ábra. Ványolómalom belseje In: Bátky Zsigmond - Győrffy István - Viski Károly 1933. I. 335. 989. kép (Lásd még Haáz Ferenc Rezső 1931. 3. ábra)

fogas hengert mozgatott, ez emelte, majd ejtette vissza a langyosra melegített vízben ázó gyapjúszövetekre az ütóbotokat ${ }^{8}$ (vö. Endrei Walter 1984. 25-26, 48; Benda Judit 2014. 29; Haáz Ferenc Rezső 1931). Ettől a folyamatos, erős dürücköléstől a cserge szálai összetömörültek és meglomosodtak. Azért, hogy a botok egyenletesen érjék a szövetet, és ezáltal az egyenletesen menjen össze, ványolás közben háromszor (reggel, délben és este) meghányták, azaz szétbontották, majd újra összehajtogatták. 24 óra elteltével bő vízben kimosták, majd a szárasztóra terítették. Száradás után szálhúzató hengeren vezették át a csergét. Ez átfésülte és föllazította a ványolás közben kialakult 5-6-7 centiméteres lomot. Végső mozzanatként rövid időre egy belülről faszögekkel tüskézett forgódobba tették, amelybe $\mathrm{kb} .50^{\circ} \mathrm{C}$-ra melegí- tett vizet öntöttek. Ebben az ún. melegítóben forogva a szegecsek hatására a lomok töve is megerősödött, tartósabb lett, a használat során még nehezebben hullott el. Szárítás után a cserge visszakerült gazdáához (Haáz Ferenc Rezső 1931; 1939; Bátky Zsigmond - Györffy István - Viski Károly 1933. I. 345347; Bartha Károly, N. 1932. 22-23; Gáspár Gyula 1939. 661; Szentimrei Judit 1972. 183-184; Szolnoky Lajos 1991. 367-368. vö. Gönyey (Ébner) Sándor 1946. 86-87; 1954. 43-45; 1960. 351; Tagán Galimdzsán 1935. 86; Ozsváth Gábor Dániel 2011. 126-140).

$\mathrm{Az}$ asszonyok - a környékbeli ványolók mellett - messzebbre is elvitték csergéiket ványoltatni. (Az egyik leghíresebb a lövétei ványoló volt. Már Orbán Balázs is megemlékezett róla. - Orbán Balázs 1868-1873. I. 83.) Még akkor nyáron feltekerték, zsákba vagy 
nagy, ún. vékás posztótarisnyába tették a megszőtt takarót, egy alkalmas napon hátukra kötötték a darabonként jó hat-hét kilós terhet, s gyalogosan keltek vele útra. Utóbb már voltak olyan ványolósok, akik szekérrel járták be a vidék falvait, havonta összegyüjtötték, majd vissza is szállították az elkészült csergéket. Ezt mindenütt hamar megkedvelték az asszonyok, mert sok fáradtságtól kímélte meg őket. Minden faluban volt olyan gazda, aki a vállalkozóval megegyezve, a maga portáján gyűjtötte össze a ványolnivalót. A ványolósok alkalmanként 15-20 települést is végigjártak, ezért pontos nyilvántartást kellett vezetniük arról, hogy az egyes szöveteket mely faluból hozták el, s hová kell visszavinniük. Egyenes és kör alakú vonalakból, illetve bevágásokból és lyukakból mindegyikük maga alkotta meg (vagy vette át elődjétől) az egyes falvak jegyeit, amelyeket a szőttemény szélére tettek (vö. Kardalus János 1977; 1980). Az elkészült darabokat e jegyek alapján csoportosítva rakták szekérre, és vitték vissza a falvakba. Az asszonyok vagy családtagjaik aztán a ványolóssal egyezségben lévő házhoz mentek el, s ott a saját maguk által belevarrt jegy alapján keresték ki a maguk csergéjét.

\section{A cserge használata, ápolása}

A ványolóból hazakerült, hozományba szánt csergét eltették. Legtöbbször abban a ládában vagy ágyban tartották, amelyben a kelengye többi darabját is gyüjtötték. A hozományba adott cserge mennyisége, nagysága, színe, mintáinak kidolgozottsága mind-mind a lány vagyoni helyzetét mutatta. Úgy tartották, ha egy nő megbecsüli, rendben tartja a csergét, akkor az élethosszig is eltart. Amikor asszony lett a lányból, akkor vették használatba, tették bele a vetett ágyba, s takarództak vele. A használatra váró vagy egy időre félretett csergébe diófalapit, dohánylevelet, később naftalint raktak a molyok elleni védekezésül.

Évente egyszer, nagypéntek reggelén, a nagyheti takarítás részeként mindenféle gyapjúból készült holmit (csergét, gyapjúlepedőt, párnákat, derékaljakat stb.) kihordtak a házból, kerítésekre, kifeszített kötelekre, drótokra teregették, s estig ott szellőztették. Azt tartották (és tartják ma is), hogy a nagypénteken meglevegőztetett gyapjút nem eszik meg a molyok.

A használat során természetesen a cserge is elpiszkolódott, időnként ki kellett mosni, hogy felfrissüljön. Évente, kétévente kerítettek erre sort. Egy nagy cseberbe tették, langyos vizet öntöttek rá, és megáztatták. Áztatóvíznek - ha csak lehetett - frissen fogott esővizet használtak. Ezzel legalább egy napot vártak, hogy leülepedjen, és csak azután öntötték rá a mosásra váró csergére. Ennél is jobbnak tartották a zsíros gyapjú levét, mert - tapasztalatuk szerint - abban tisztult, lúgozódott ki legjobban a gyapjúholmiba rakódott piszok. A jól megáztatott csergét átdörzsölték, majd a patakra vitték, és a mosópadon alaposan átsulykolták. Mosás után a nagyméretű és a víztől még inkább megnehezedett csergével egy ember nehezen tudott bánni, segítség kellett a kicsavarásához és a kiterítéséhez is. A segítővel otthon rúdra vagy kerítésre tették az udvaron, ahol a nap érte, és a levegő átjárhatta. Ott száradt meg és frissült fel. Mosásra és szárításra, ha csak lehetett, meleg, napsütéses időt választottak. A nagy, vastag csergét ugyanis a házban csak nehezen tudták szárítani. Az volt a tapasztalat, hogy a kényszerűségből benn a házban, tűz mellett szárított cserge lomja a használat során megtört, majd maga a szövet is hamarosan meglyukadt.

Ha nem volt mód a mosásra, akkor az elpiszkolódott csergét a posztóharisnyákhoz 
hasonlóan az udvar füves részén terítették ki, illetve egy szélesebb asztalra fektették fel, puliszkaliszttel behintették (utóbb boltban vásárolt benzint is adtak a puliszkaliszthez), a lisztet tenyérrel besúrolták a szövetbe, majd szárítókötélre vagy drótra emelték át. Itt aztán egy pálcával jól megverték, hogy hulljon ki belőle a liszt s vele együtt a rátapadt piszok. Akár mosták, akár puliszkaliszttel tisztították a csergét, befejező mozzanatként gyér fogú fésűvel fésülték át a lomját, s utána vitték vissza a szobába, vették újra használatba. Ha már évek óta használták, többször tisztították, megkopott a lom. Ilyenkor újra megványoltatták és tépették, hogy újra meglomosodjon. A jó lomosra ványolt csergét tartották ugyanis igazán becsüsnek.

A csergék sem örök életűek. A régóta használt, esetleg az elhalt szülőktől örökölt, megkopott, lomjukat vesztett csergék kikerültek a családi ágyból. Előbb szénacsináláskor vitték magukkal takarónak, ha azokra a távoli, havasi kaszálókra mentek föl, ahonnan nem jártak haza mindennap. Aztán a szekérre került át, s hideg időben ebbe burkolództak az úton járók. Ha végképp megkopott, lópokrócnak használhatták, de olyan asszony is volt, aki a falut járó öreg koldusnak adta oda.

\section{A cserge készítésének átalakulása}

A kommunista-szocialista rendszer által a lakosságra erőltetett kollektivizálás az élet számos területén jelentős változásokat hozott. A családi juhtartás - ha nem is szűnt meg - lényegesen visszaszorult. Ennek következtében a gyapjú házi feldolgozása szinte teljesen eltűnt. A II. világháborút követő években a kötelező beszolgáltatás miatt kialakult gyapjúszúke hatására a 3-4 év alatt összegyújtögetett gyapjúból inkább posztónak való szövetet szőttek, hogy a férfiak az abból készült ruhában tudjanak az erdőre járni. A lányok kelengyéjét ez idő tájt apránként összerakosgató családok jórészt csak pénzért tudták megvásárolni a különböző tárgyakat. Az anyáknak, nagyanyáknak kevesebb módjuk volt otthon szőni, ezért ezzel foglalkozó helybeli specialistával vagy a háziipari szövetkezetek valamelyikében készíttették el a szőtteseket.

Ha volt otthon összegyűjtött gyapjújuk, akkor azt elvitték magukkal. Ha találtak kedvükre való kész szőttest a szövetkezet boltjában, lerakatában, már vihették is, ha nem, akkor meg kellett rendelni, s az igényeknek megfelelőt szőttek a bedolgozók. A késztermék árának egy részét a magukkal hozott gyapjúval rótták le, a munkadíjat mindenkor pénzben fizették. $1 \mathrm{~m}^{2}$ szôtteményre $1 \mathrm{~kg}$ gyapjút számoltak. Akinek nem volt gyapjúja, természetesen a teljes összeget pénzben fizette ki.

A házasuló fiatalok igényei időközben megváltoztak, már nem a hagyomány, hanem a kor divatja volt a meghatározó. A szövetkezetek bedolgozói igyekeztek a régi hagyományok megőrzése mellett az új elvárásoknak is megfelelni. Ezért az 1950 után készült csergéken is az adott időszak egyes divatszínei és a külvilág hatására változó egyéni ízlés is nyomon követhető. Adatgyűjtésem során annak idején ilyenekkel is találkoztam. Az egyik háznál például a háziasszony megmutatta féltve őrzött, 1954-ben a háziipari szövetkezetben szövetett csergéit. Mindkettőt hozományba hozta magával. Az egyik hagyományos fehér-szürke, kockásan szőtt, a másik teljes egészében narancssárga színú.

A Székelyföldön ma sok háznál találkozunk az újabb típusú, vastag fonalból szőtt, bedolgozók, illetve specialisták által készített szőttesekkel. Ezek ványolva nincsenek, de mivel fehér, szürke vagy barna színű, vastag gyapjúfonalból készültek, ma ezeket is csergének 
mondják. Ezek három, egymástól jól elkülöníthető csoportot alkotnak.

Az elsőbe azokat sorolom, amelyek mintakincse és szövési technikája a hagyományos székely festékesekkel, rakottasokkal egyező, de a gyapjú természetes színeit használják benne, és vastag fonalból készítik. Van, aki ágy előtti szőnyegnek, van, aki ágytakarónak használja.

A második típus az ún. lomos vagy lombos cserge. Szövéstechnikája emlékeztet a gubakészítésre (vö. Luby Margit 1927; Flórián Mária 1997. 629-632; 2001. 165-168.). Az egyes sorok leverése után ugyanis a juhok oldalán nőtt, hosszú, erős szálú gyapjúból, külön erre a célra durgált, alig sirített gombolyagot raktak maguk mellé a szövők. Három ujjukat összecsippentve egy 10-12 centiméteres tincset téptek ki belőle. A szélső szálakat kihagyva ujjukkal megemeltek négy felvetőszálat, és behúzták alá a tincset. Ezután téptek egy újabbat, ismét megemeltek négy másik felvetőszálat, $\mathrm{s}$ behúzták alá. Amikor végigértek a soron, a tincseket lekísérték, azaz a cséppel átvezették fölöttük a vetülékszálat, és a bordával jó erősen rávertek. A tincsek végei kilógtak a szövetből, gubára emlékeztető felületet képeztek. A lombos csergét általában egyszínű fehérre szőtték, de itt is előfordult a már említett geometrikus díszítés: a tincsekből vízszintes csíkozást, a sarkokra vagy középre négyzetet, rombuszmintát, esetleg a négy szélen körbefutó szélesebb keretet készítettek. Az elkészült cserge lombját átfésülték, hogy a tincsek eligazodjanak, szép szálasak legyenek, és már használhatták is - elsősorban ágy- és foteltakarónak.

A harmadik csoportba az ún. bogos vagy bogyós csergék tartoznak. Ezeknél is ujjnyi vastagra durgált, alig sirített, általában nyers és szürke színű fonallal dolgoznak. A bogok ki-

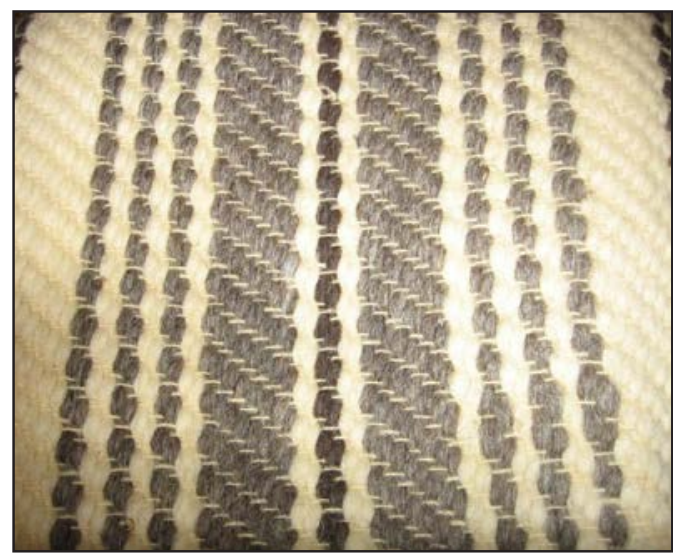

14. kép. Vastagra durgált fonalból szőtt ágytakaró, „cserge" (Kerekes Ibolya felvétele)

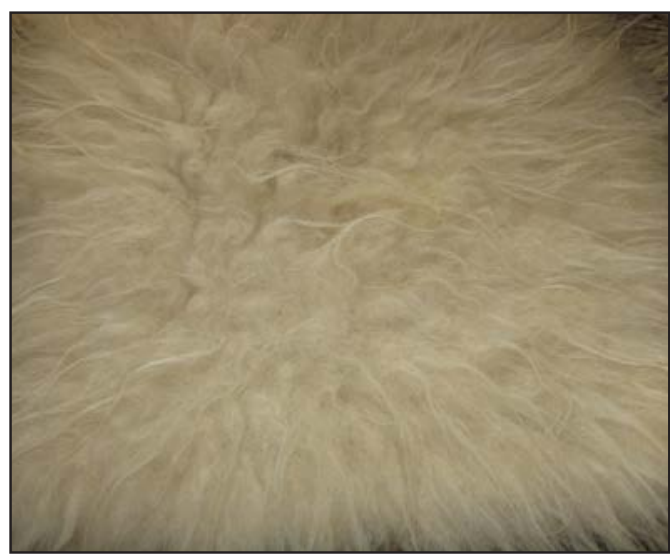

15. kép. Lomos cserge (Kerekes Ibolya felvétele)

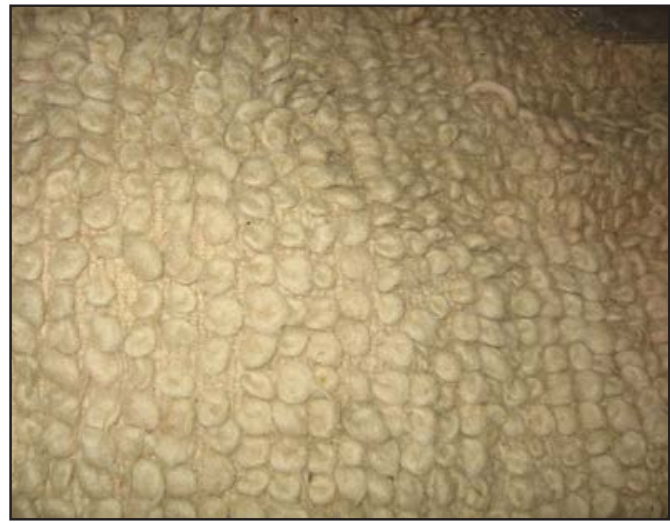

16. kép. Bogosan szőtt ágytakaró „cserge"(Kerekes Ibolya felvétele) 
alakításához egy vékony (általában műanyag borítású) vaspálcát használnak, amely valamivel hosszabb, mint a szövőszéken készíthető szövet szélessége. A legegyszerűbb mintázat kialakításához három-négy sor leverése után a következő sor fonalát minden negyedik-ötödik felvetőszál között benyúlva kihúzogatják, s a fonal alá csúsztatott vaspálcára emelik rá. Attól függően, hogy hányadik felvetőszál után nyúltak be, s emelték meg kissé a fonalat, sűrübben vagy ritkásabban sorakoztak a bogok. A sor leverése után kiveszik a pálcát, három-négy simán levert sor után veszik ismét kézbe, hogy ráemeljék a bogokat. Hasonló technikával készíthetnek négyzet, illetve rombuszmintákat is a szövetbe. Találkoztam olyan asszonnyal, aki „, $a$ forradalom után", 1991-ben tanulta meg a technikát. Ő vaspálca helyett a kicsid ujját használja a bogok kiemelésére. Szőtteseit a nála megszálló magyar turisták vásárolják meg, s viszik magukkal mint „eredeti erdélyi csergét".

Az új típusú „csergéket" nem ványolják, s az utóbbi két típusról az is elmondható, hogy a II. világháború előtt férjhez ment asszonyok egyike sem emlékezett arra, hogy akár ők, akár környezetük szőtt - vagy akárcsak látott - volna ilyet. Készítésükről a csak „fiatalabbak" tudtak beszámolni. Ebből arra következtethetünk, hogy ezek a háziipari szövetkezetek létrejötte után terjedtek el a Székelyföldön (vö. Márton Béla 1993. 23.).

\section{Összegzés}

Századokon át generációk adták át egymásnak a csergekészítés ismeretét. Minden csíki leány anyjától, nagyanyjától tanulta el a mozdulatokat. Hozományuk része volt egykét maga szôtte cserge. A kelengyébe vitt ágy felszereléséhez ugyanúgy hozzátartozott, mint a szalmazsák, lepedő, derékalj, párna, később a paplan. Férjhezmenetelük után vették használatba, s takarództak vele. Különbséget tettek a gyapjúpokróc és a cserge között. Csergének csak az alig sirített, ujjnyi vastagra durgált fonalból készített, ványolt $\mathrm{s}$ a ványoláskor meglomosodott, vastag, puha, meleg takarót nevezték.

A 20. század közepén hatalomra jutott kommunista-szocialista vezetés a Székelyföldön is minden eszközzel igyekezett felszámolni a hagyományos paraszti kultúrát. De - mint oly sok területen - itt sem jártak teljes sikerrel. Az élet jelentősen átalakult ugyan, de a közösségi munkamegosztásnak ez a sok emberöltő alatt kialakult formája búvópatakként a szocialista időszakban is tovább élt. Mindvégig voltak olyanok, akik - ha kevésbé nyilvánosan is - nemcsak önellátásra fontak, szőttek gyapjút. Egyes falvakban a családi bevételek kiegészítésére több asszony specialistaként foglalkozott a csergekészítéssel, ezzel egészítve ki a szűkös családi bevételeket. Munkájukkal tovább éltették a kézmûvességnek ezt az ágát. Náluk meg lehetett rendelni a hozományba szánt csergét vagy pótolni az elhasználódott takarót. Legfőképpen télre vállalták a szövést. A megrendelő hozta a megfelelő mennyiségú füsült gyapjút, a specialista pedig megdurgálta és megszőtte. Egy-egy ügyesebb asszonynak hamar elterjedt a híre, többen is fölkeresték. Mivel a munkáért kapott pénzből nem fizettek adót, olcsóbban is dolgoztak, mint a háziiparban, nehogy valaki följelentést tegyen.

Mások „hivatalosan", az 1950-es évektől létrejött háziipari szövetkezetek bedolgozóiként vállaltak munkát. E szövetkezetek mára mindenütt fölszámolódtak. Elvétve akad csak olyan, amely az egyéni vállalkozók befektetésének és igyekezetének köszönhetően túlélte az 1989-et követő gazdasági változásokat. A csíkkarcfalvi az egyik ilyen kivétel. Gépeit 
1991-ben egy vállalkozó szellemű, fiatal házaspár - Mózes Csaba és felesége, Annamária - vette át, s kezdte el újra múködtetni. Kezdetben csak fonalelőkészítéssel (mosással, tépéssel, fésüléssel, fonással) foglalkoztak. A gyapjúfonalat az akkor még működő csíkszentdomokosi szövetkezet vásárolta meg tőlük. A domokosi vállalkozás azonban lassan hanyatlani kezdett, végül csődbe ment. Mózesék továbbra is láttak viszont fantáziát a nagy múltú csíki székely festékesek készítésében, ezért 1997-ben Segesvárról régi, használt gépeket vásároltak részletre, megtanulták a gépek kezelését, karbantartását, munkatársakat vettek fel, s lassan bővíteni tudták vállalkozásukat. Mára egész Csíkban ismert a Mózes család gyapjúmanufaktúrája.

Ahol nem élték túl a rendszerváltást a hajdani szövetkezetek, és nem volt, aki tovább működtesse őket, ott is megmaradt az egykori bedolgozó szövőasszonyok tudása. Néhányan közülük újra elővették szövőszékeiket, családjuknak vagy egyéni megrendeléseket teljesítve újra szőnek.

Amíg régen a hagyományos lomos csergékből általában egyet vagy kettôt adtak hozományba, addig az 1960-1970-es években elterjed új típusokból garnitúrát rendeltek a férjhez menő leány szülei. Egy ágytakaró, két foteltakaró, egy falvédő és egy asztalra való terítő alkotja ma is a garnitúrát. A felhasznált fonal vastagsága és az alkalmazott színek magyarázhatják azt, hogy ezeket is csergének mondják. Az új típusok azonban elsősorban lakásdíszítő funkcióval bírnak. Ezekkel a „csergékkel" (vastag fonalból szőtt, dísztárgyként használható szőttesfajtákkal) találkozhatunk ma a kirakodóvásárokon, turisták által látogatott idegenforgalmi nevezetességek közelében, frekventált fóútvonalak mentén létesült bazársorok pavilonjaiban.

Napjainkban azokat a régi, egykor hozo- mányba készített lomos csergéket, amelyeket jó állapotban örököltek meg az utódok, többnyire nagy becsben tartják. Néhol annyira, hogy nem is használják, szekrények, ágyak mélyén őrzik, csak a nagypénteki szellőztetésre viszik ki a házból. Ahol nem féltik annyira, ott főleg ágytakaróként találkozhat velük a betérő. Használatban leginkább azoknál láttam, akik az 1950-es évek előtt kötöttek házasságot. Ma már ők is főképp ágytakarónak használják. Vannak, akik az ágyban terítik maguk alá, erre teszik a lepedőt - így melegítve fázós lábukat, fájós derekukat. Néhány olyan öreggel találkoztam csak, akik takarózásra használják régi csergéjüket, ők is jobbára az ebéd utáni pihenés idején. A cserge eredeti (meleget adó takaró) funkcióját az 1950-es évektől mindenütt egyöntetűen a paplan vette át. Az egykori ványolt, lombos csergék lassan kikopnak a mindennapos használatból. Napjainkban csupán néhányat láthatunk, „hírmondóikkal" találkozhatunk a Székelyföldön.

\section{Jegyzetek}

1. N. Bartha Károly az Udvarhely megyei Bágy község csergekészítéséről írt közleményének elején megjegyzi: „A cserge készítése csak Bágyban van szokásban, sem a szomszédos vidéken, sốt más székely megyében sem foglalkoznak vele, csupán bent Csíkban." Bartha Károly, N. 1932. 19.

2. A juhtartó családok kisebb-nagyobb esztenagazdaságba (esztenaközösségbe, esztenatársulatba) szerveződtek, egyéni tulajdonban lévő állataikból közös juhnyájat hoztak létre. A gazdasági együttműködésnek ez a formája Erdély egész területén ismert. Az esztenagazdaság élén az esztenabíró állt, akit tagjai közül választott a közösség. Feladatai közé tartozott a különféle hivatalos fórumokon saját közösségének képviselete, érdekérvényesítése, pásztorok fogadása, a legeltetés fi- 
gyelemmel kísérése, a tejfeldolgozás és a tejtermékek elosztásának szabályozása, a szükséges közösségi munkák megszervezése, lebonyolítása. Egy faluban több ilyen társulás is működhetett. Szerveződésének alapja általában az adott település hagyományos közigazgatási egysége volt, de előfordulhatott, hogy a falun belüli egyéb területi egység, illetve rokonsági kapcsolatok révén alakult juhtartó közösség (vö. Paládi-Kovács Attila 2001. 613-614.).

3. 1 ige kb. 12 méternyi fonalat jelent. Vö. Szolnoky Lajos 1950; 1991. 359.

4. Felcsíkon például a nyers és a szürke mellett öt színt kedveltek: pirosat, fehéret, zöldet, sárgát és kéket. Az alcsíkiak többnyire szürke, fehér, piros színből szőtték csergéiket.

5. Csak egy példa: a csíkszentgyörgyi Jenőfalva tizesben élő Vitos Erzsike (Vitos Gyuláné Basa Erzsébet) sok csergét szőtt eladásra. 80 centiméter széles bordájába 140 szálat tudott befüzni. Elmondása szerint két, $3 \mathrm{~m}$ hosszú szél elkészítéséhez $2 \times 6 \mathrm{~m}$, azaz összesen $12 \mathrm{~m}$ fonalat tekert fel a vetőfára. Kis ráhagyással ehhez mérte hozzá 140-szer a mellyéknek font szálat. Ezt a fonalmennyiséget vetette föl aztán az osztovátára.

6. Az egyik idős asszony elmondása szerint ő két csergét szőtt életében. Azt a kettőt, amelyet hozományként hozott magával 1941-ben. Szövésüket akkor kezdte el, amikor menyasszony lett.

7. Láthattam olyan, még a kicsi magyar világ előtt, 1937-ben készült takarót is, amelynek széleit piros, fehér, zöld csíkozással szőtték. Mégsem „nemzeti zászló" lett belőle, mert készítője a két szélsőnek szánt szövetet piros fonallal kezdte, a középső csíkot viszont fehérrel. Így a szélek összeöltése után az egyes színek mozaikszerūen helyezkedtek el a cserge felületén, diszkréten, mégis egyértelmúen kifejezve készítője és használója nemzeti hovatartozását.
8. Jó illusztrációkat láthatunk erről a $M a-$ gyarság néprajza I. kötetének 989. és 991. ábráján. Bátky Zsigmond - Györffy István - Viski Károly 1933. I. 335, 336.

\section{Felhasznált irodalom}

Bálint S.: Ünnepi kalendárium. A Mária ünnepek és jelesebb napok hazai és közép-európai hagyományvilágából. I-II. Szent István Társulat, Budapest, 1977.

Bartha Károly: A cserge készítése az udvarhelymegyei Bágy községben. Néprajzi Értesítő XXIV. (1932) 19-23.

Bátky Zsigmond - Györffy István - Viski Károly: A magyarság néprajza. I. kötet. (1. kiadás) Budapest, 1933.

Benda Judit: Posztókereskedelem és posztóboltok a későközépkori Budán. In: Szulovszky János (szerk.) A textilmüvesség évezredei a Kárpát-medencében. Az anyagi kultúra a Kárpát-medencében 5. MTA VEAB Kézművesipar-történeti Munkabizottság, Budapest, 2014. 2742.

Benkő Loránd (főszerk.): A magyar nyelv történeti-etimológiai szótára. 1. Akadémiai Kiadó, Budapest, 1967.

Csókos Varga Györgyi: Tárgyi anyanyelvünk. Szent Gellért Egyházi Kiadó, Szeged, 1992. Csókos Varga Györgyi: Fonás, vetés, szövés. Planétás Kiadó, Budapest, 1998.

Domokos Pál Péter: A kender feldolgozása és eszközei Menaságon. Néprajzi Értesítő XXII. 3-4. (1930) 145-149.

Endrei Walter: Patyolat és posztó. Magvető Könyvkiadó, Budapest, 1989.

Farkas Irén: Hagyományos népi gyapjúszőttes Csíkban: a cserge. In: Murányi János (szerk.): A Csíki Székely Múzeum Évkönyve 2007-2008. Humán- és Természettudományok. Csíki Székely Múzeum - ProPrint Kiadó, Csíkszereda, 2008. 127-150.

Fél Edit - Hofer Tamás: A kalotaszentkirályi kelengye. I. Néprajzi Értesítő LI. (1969) 15-36. 
Flórián Mária: Gyapjúszövet, szürposztó ruhák. In: Balassa Iván (főszerk.): Magyar néprajz IV. Életmód. Akadémiai Kiadó, Budapest, 1997. 616-632.

Flórián Mária: Magyar parasztviseletek. Planétás Kiadó, Budapest, 2001.

Gáspár Gyula: Abaposztó, cserge, lomospokróc. Búvár V. 9. (1939) 659-664.

Gönyey (Ébner) Sándor: Gyapjú- és kenderguzsaly a Radnai havasok alján. Ethnographia LIV. 1943. 191-192.

Gönyey (Ébner) Sándor: A gyimesi csángók gyapjúmunkája. Ethnographia LVII. 1946. 86-87.

Gönyey (Ébner) Sándor: Nagybajomi kapcások ősi gyapjúkallója. Néprajzi Értesítő XXVI. 1954. 43-45.

Gönyey (Ébner) Sándor: Ôsi gyapjúványoló a mezôségi románoknál. In: Gunda Béla (szerk.): Műveltség és hagyomány. I-II. Tankönyvkiadó, Budapest, 1960. 351-357.

Haáz Ferenc Rezső: A székely ványoló. Néprajzi Értesítő XXIII. 1931. 55-62.

Haáz Ferenc Rezső: Udvarhelyszéki mesterségek. Erdélyi Múzeum XLIV. 1939. 365-370.

Hajdú Farkas-Zoltán: A csíki kaláka. Pro Print, Csíkszereda, 1993.

K. Csilléry Klára: Cserge. In: Ortutay Gyula (főszerk.): Magyar Néprajzi Lexikon. I. 1977. 498.

Kardalus János: A Homoród menti posztóványolók íratlan nyilvántartása. Művelődés XXX. 7. (1977) 53.

Kardalus János: Posztó- és csergeványolás a Kis-Homoród mentén. Acta Hargitensia 1. 1980. 223-234.

Kardalus János: Maszók szőnyeg és gyapjú-cserge készítése Bágyban. In: Cseke Péter - Hála József (szerk.): A Homoród füzes partján. Dolgozatok a Székelyföld és Szászföld határvidékérôl. Pro-Print, Csíkszereda, 2000. 219-224.

Kerekes Ibolya: A csíki cserge. Libelli Transilvanici 5. Kecskemét, 2008.
Kerékgyártó Adrien: Csíkmenasági leltárak (1779-1930). Néprajzi Értesítő LXIII-LXVI. 1984. 71-163.

Kós Károly: Erdélyi guzsalyok. In: Kós Károly: Eszköz, munka, néphagyomány. Dolgozatok a munka néprajza köréből. Kriterion Könyvkiadó, Bukarest, 1980. 108-130.

Luby Margit: A guba készítésmódja és a gubásmesterség. Néprajzi Értesítő XIX. 4. (1927) 144-154.

Márton Béla: A parajdi csergeszövés. Hazanéző IV. 2. (1993) 22-23.

Márton Béla: Gyapjúfésülés a Maros megyei Kibéden. Néprajzi Látóhatár IV. 3-4. 1995. 122-127.

Miklóssy V. Vilmos: Festőnövények a csíki háziiparban. In: Kós Károly - Faragó József (szerk.): Népismereti dolgozatok. Kriterion Könyvkiadó, Bukarest, 1978. 91-100.

Nagy Jenő.: Orsófaragás a kalotaszegi Magyarvalkón. Ethnographia LVIII. 1947. 264-266.

Nagy Mari - Vidák István: Csergeványoló kádak a Székelyföldön. Ház és Ember, 26. 2014. 159-171.

Nagy Ödön: A havadi juhtenyésztés. In: Keszeg Vilmos (szerk.): Kriza János Néprajzi Társaság Évkönyve 1. Gloria Kiadó, Kolozsvár, 1992. 24-36.

Nécsey Isván: A gyapjúguzsaly és orsója. Néprajzi Értesítő I. 4. (1900) 39-50.

Orbán Balázs: A Székelyföld leírása. I-VI. Pest, 1868-1873

Ozsváth Gábor Dániel: Patakmalmok a Kárpát-medence keleti felében. Terc Kereskedelmi és szolgáltató Kft., Budapest, 2011.

Ozsváth Gábor Dániel: $A$ vízerő hasznosítása a Kárpát-medence népi textilmunkáiban. In: Szulovszky János (szerk.): A textilmüvesség évezredei a Kárpát-medencében. Az anyagi kultúra a Kárpát-medencében 5 . MTA VEAB Kézművesipar-történeti Munkabizottság, Budapest, 2014. 143-154. 
Paládi-Kovács Attila: Állattartó gazdaságok. In: Paládi-Kovács Attila (főszerk.): Magyar Néprajz II. Gazdálkodás. Akadémiai Kiadó, Budapest, 2001. 599-616.

Palla Ákos: A szkíta cserga. Az Országos Orvostörténeti Könyvtár Közleményei 8-9. (1958) 218-232.

Palotay Gertrúd: A gyapjú fonása és festése Csíkszenttamáson. Néprajzi Értesítő XXIX. (1937) 273-274.

Szabadfalvi József: Juhtartás. In: PaládiKovács Attila (főszerk.): Magyar Néprajz. II. Gazdálkodás. Akadémiai Kiadó, Budapest, 2001. 732-736.

Szabó T. Attila (főszerk.): Erdélyi magyar szótörténeti tár II. Kriterion Könyvkiadó, Bukarest, 1978.

Szebeni Géza: A csíki juhászat. Ethnographia LXXIII. 1. (1962) 54-89.

Szentimrei Judit: Szôttes és varrottas munkák. In: Kós Károly - Szentimrei Judit Nagy Jenő (szerk.): Kászoni székely népművészet. Kriterion Könyvkiadó, Bukarest, 1972. 157-216.

Szentimrei Judit: Szôtttesek és varrottasok. In: Kós Károly - Szentimrei Judit - Nagy Jenő (szerk.): Kis-Küküllő vidéki magyar népművészet. Kriterion Könyvkiadó, Bukarest, 1978. 145-255.

Szentimrei Judit: Szőttesek, varrások, hímzések. In: Kós Károly-Szentimrei Judit-Nagy Jenő (szerk.): Moldvai magyar népmúvészet. Kriterion Könyvkiadó, Bukarest, 1981. 177-359.

Szolnoky Lajos: Minőségi csoportok, mennyiségi egységek és a fonalrendezés számolási rendje a kenderfeldolgozásban. Ethnographia LXI. 1-2. (1950) 29-54.

Szolnoky Lajos: Gyapjúmosás. In: Ortutay Gyula (főszerk.): Magyar Néprajzi Lexikon. II. 335.

Szolnoky Lajos: $A$ kender, a len és a gyapjú népi feldolgozása. In: Domokos Ottó (főszerk): Magyar Néprajz. III. Kézművesség. Akadémiai Kiadó, Budapest, 1991. 341-368.

Szőcsné Gazda Enikő: Erdélyi levéltári források felhasználási lehetôségei az építészet és lakásberendezés rekonstruálásában. Ház és Ember 20. (2007) 159-202.

Tagán Galimdsán: Baskír gyapjúmunka. Néprajzi Értesítő XXVI. (1934) 105-108.

Tagán Galimdsán: A baskír posztókészítés. Néprajzi Értesítő XXVII. (1935) 85-87.

Tagán Galimdsán: A gyapjú feldolgozása a kisázsiai törököknél. Néprajzi Értesítő XXXI. (1939) 231-238.

Thiering Oszkár: A textilipar. A szövés-fonás anyagai és technikája. Kultura Könyvkiadó és Nyomda Részvénytársaság, Budapest, 1925.

Timaffy László: Juhászat az Alsó-Garam mentén. In: Balázs Géza - Voigt Vilmos (szerk.): Arator. Dolgozatok Balassa Iván 70. születésnapja tiszteletére. Magyar Néprajzi Társaság, Budapest, 1987. 111-123. 58. Ujváry Béla 1993

Ujváry B.: Juhtartás Csíkmenaságon. Néprajzi Látóhatár II. 1-2. (1993) 83-94.

Zentai Tünde: $\mathrm{Az}$ ágy és az alvás története. Pro Pannonia Kiadói Alapítvány, Pécs, 2002. 


\section{GYERGYÓSZENTMIKLÓSI ÖRMÉNY TÍMÁROK HÍRNEVES TERMÉKE: A KORDOVÁN}

Az örmény iparosok két kedvenc szakmája a mészárosság és a tímármesterség volt. Egy 1820-ban végzett felmérés jól tükrözi a 19. század eleji nagyközség, Gyergyószentmiklós társadalmi, gazdasági, szakmák szerinti összetételét. A felmérés szerint: „Vagynak ezen faluban mindöszvességgel kisebbel, nagyobbjával öszvevéve 15 kereskedö boltok[...] Mesterséget üző emberek e következendő számmal: kenyérsütők a piac számára vannak 25, zsemlesütố 2. Mészárosok vannak 40. Korcsomárosok vannak - nagyobb részüek -10. Csizmadiák vadnak 30, suszterek 2. Szabómesterek 10, Kovácsmesterek 12, lakatos 2, asztalos 10, ács 2, kerekes 2[...], Kömives mesterek vannak, numero 6. Kádármesterek 13, malommesterek 20, üveges mesterek 4, füsús- mester 1, kéményseprő 1 , serfóző 1, szatler 1, szíjgyártó (!) 2, talpérdő tímár 2, chirurgus 4, borbélymihely 2, kordovány csináló tímárház 6. Nota bene: de egy házban 10-en, s többen is dolgozni szoktak." (Csík-, Gyergyó-, Kászonszék és Aranyosszék parasztvallomásai 1820-ból)

A kérdőív 13. pontjában a "hasznos fabrikák" szomszédságáról kérdésre adott válasz: „Az említett kordovány készítő fabrikákon, a borszéki üvegcsúri fabrikán kívül (!) itt egyebek nincsenek."

A tímárság mint önálló kézmúipar aránylag későn, a 18. század közepén jelent meg Gyergyóban. A nyers bőrök kikészítését a helyi lakosság végezte szükségletei szerint. Miért éppen az örmény iparosok lettek a tímár- ságnak mint önálló iparnak megteremtői, művelői? Az örmény kereskedők közép-keleti, oroszországi kapcsolatai, forrásai lehettek az új szakma, a kordován készítő tímárság megismerésének, elsajátításának. Érdekük volt, hogy termékeikkel a piaci versengésben is megállják helyüket, hogy a legjobb minőségű áruval jelenjenek meg a piacon, ahol már jelen voltak a Konstantinápolyból, Cordobából, Avignonból, Párizsból és Európa más részéből származó gyártmányok (Möller János 1818).

A kordovánt gyártó kézműipar mennyiségi és minőségi árutermelése, jelenléte külhoni piacokon egyik fontos tényezője lehetett a gyáripar kialakulásának. Hogy valóban a bőrkikészítés kézműipari fázisa volt a kezdetleges gyáripar kialakítója, mi sem bizonyítja jobban, mint a tímárházak száma és a mesterséget gyakorló személyek, akik egy tímárházban dolgoztak. Ha csak egy tímárház dolgozóinak számát vesszük számításunk alapjául, ami tíz vagy még több személyt jelent, Gyergyószentmiklóson 1820-ban a hat tímárház dolgozóinak létszáma jóval meghaladja bármelyik kézműipar foglalkoztatottjainak számát.

A gyergyói bőripar nem a mai ipari szemléletünknek megfelelő méretű és műszaki felszerelésű tevékenység volt. Ezt azok a rendelkezések is tükrözik, amelyek a tímárházak létrehozását és múködését szabályozták. Tímárház csak a településen kívül működhetett, a vegyi anyagokkal telített szennyvizek- 


\begin{tabular}{|c|c|}
\hline 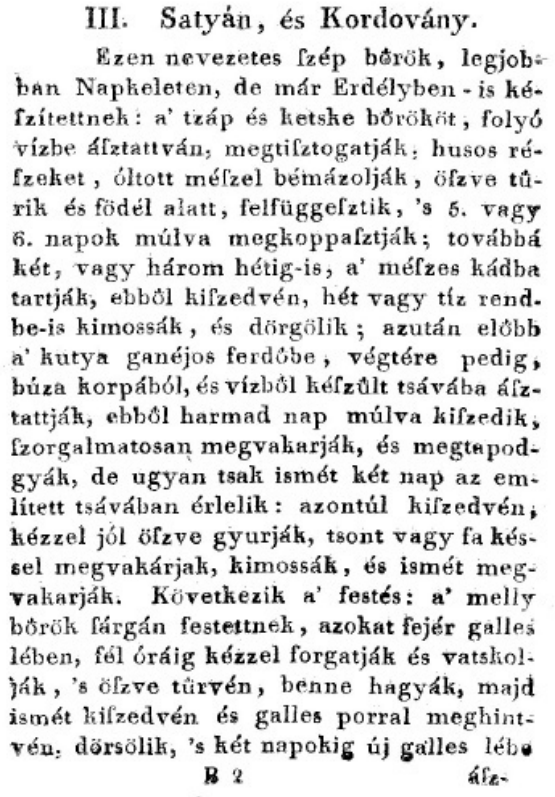 & 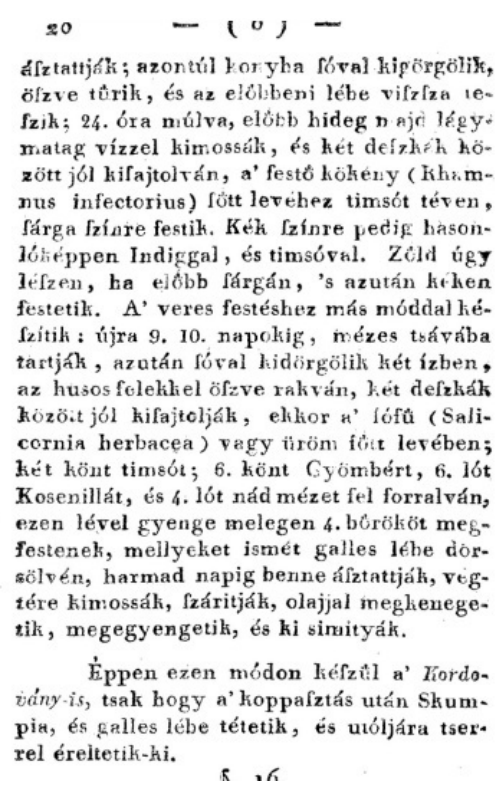 \\
\hline
\end{tabular}

1. kép. Gergelyffi András könyvének 19. és 20. oldala a „Satyán és Kordovány” készítéséről

tisztítása, ülepítők építése és használata kötelező volt. A rendelkezések be nem tartását szigorúan bírságolták, eljárásokat indított a helyi hatóság azok ellen, akik az ülepítőket kiiktatták, vagy nem takarították rendszeresen. Így próbálták tisztán tartani a patakok vizét, amelyekből a helyi lakosság állatait itatta.

A kordován gyártásának technológiáját korabeli dokumentumok, könyvek szűkszavúan tárgyalják. Azt vitathatatlanul leszögezik, hogy bakkecske bőréből „tsaknem azon módon készítetnek valamint a szattyánok; mindazonáltal nem kutya rezelettel hanem tserrel". (Gergelyffi András 1809)

Teljesebb képet nyújt a kordovángyártásról Gergelyffi András 1809-ben Pozsonyban kiadott múve, amelynek 19-20. oldala részletes leírását tartalmazza az egykor keresett bőripari termék, a kordován gyártástechnológiájának.
Mindkét említett forrás, bár megjelenésük között kilenc év különbség van, leszögezi, hogy eltérően a szattyán kikészítésétől a kordovánnál nem használtak kutyaürüléket. „E helyett skumpia és galles lébe tétetik, és utoljára tserrel éreltetik-ki."

Mint általában lenni szokott, minden terméknek van életútja. Az elején felugrik a kereslet, majd egy idő után hanyatlásnak indul, a termék iránti érdeklődés lecseng. Ez tapasztalható volt a kordovánnál is. 1800ban Gyergyószentmiklóson a kordován fabrikák száma 20, 1820-ban 10, két év múlva, 1822-ben ez a szám már csak 6 volt. ${ }^{4}$

A kordován többféle finomságú és színű, nagyon finom tapintású bőripari termék volt. Az örmény kordovánkészítők jobb időkben 1000 köteg kordovánt is gyártottak, minden egyes köteg hat darab bőrt tartalmazott, négy feketét, egy pirosat és egy más szinűt. Ezt az 1000 köteget el is adták, nehézség nélkül. A 
hatezer bakkecskebőr beszerzése nagyobb gond volt, mint a késztermék értékesítése.

A kordován gyártástechnológiájának olyan részletei is vannak, amelyeket a mesterek féltve őriztek, noha az előbbiekben bemutatott gyártási eljárás mondhatni minden tudnivalót tartalmaz ahhoz, hogy bárki kordovángyártó legyen. Természetesen ez nem így volt. A titkok, a mesterfogások, mint pl. a cserző- és csávázóanyagok arányos keverékei, ezek vizes oldatának koncentrációja, a folyamatok pontos időtartama, hőmérséklete megannyi apró részletkérdés, amiket kizárólag a mester birtokolt. Ezek a szakmai titkok és sok más tapasztalati tényező, amiket nem írtak le, apáról fiúra szálltak, a fiú vagy vő örökölte ezeket, ha folytatták apjuk, apósuk szakmáját. Csak nagyon ritkán avattak be családon kívüli személyt féltve őrzött szakmai titkaikba. Az ilyen szakmai titoktartás a kézműiparok összességére jellemző volt.

A kordovángyártást az ipar fejlődése során a bőrgyárak váltották fel, a cipő felváltotta a csizmát, a bőrkabátot az ipari textíliák világa követte. Lassan, de biztosan fogyatkozott, majd megszűnt egy székelyföldi örmény kézmúipar és az örményekre jellemző, mindennapjaikat meghatározó tevékenység, hagyomány és ezzel együtt maga a gyergyói örménység is. Ma már alig van néhány család, amely tisztán örménynek vallhatja magát Gyergyóban. A kordovángyártás eltűnt. Az örmények egykori jelenlétét a településkép meghatározó elemei, az épített örökség, a templomok őrzik, hírmondóiként egy sokat szenvedett, tevékeny, városalakító népességnek.

\section{Felhasznált irodalom}

1. Csík-, Gyergyó-, Kászonszék és Aranyosszék parasztvallomásai 1820-ból. A forrásokat sajtó alá rendezte és kiadja Takács Péter. Debrecen, 2002. 98.

2. Möller János: Az erurópai manufaktúrák és fabrikák. Mesterség Míveik. Pesten 1818, 397.

3. Gergelyffi András: Technologia, vagyis a mesterségek és némely alkotmányok rövid leírása. Pozsony 1809. 19-20.

4. Tarisznyás Márton: Gyergyó történeti néprajza. Kriterion Könyvkiadó, Bukarest, 1982. 99. 


\section{A KovásZnAI POSZTógYáR}

Kovászna a Háromszéki medencében, a Kárpátok lábainál fekszik 550 méter magasan a tengerszint fölött. Az egykori Orbaiszék központja, 1876-tól járási székhely, 1952-től város, 1968-tól Kovászna megye névadó települése. Az idők során Vajnafalva olvadt bele. (Benkő-Fábián 2007. 11.).

A gyapjúfeldolgozás a kezdetekben házi mesterségként létezett. A gyapjút megmosták, ványolták, fonták, festették és megszőtték, mindez többnyire a nők feladata volt. Köztudott, hogy a gyapjúval, miután a juhról lenyírták, azonnal dolgozni kezdtek, mert a gyapjú, ha nem dolgozzák fel időben, veszít a minőségéből. Kezdetben a megmosott, szárított gyapjút kézi orsóval fonták, a szövőszékek is általában kisméretű, házi készítésű szerkezetek voltak. A gyapjúfeldolgozással kapcsolatosan olvassuk el az alábbi szakirodalmi bejegyzéseket:

„Kovásznán a többségében (71\%) magyar lakosság mellett románok is éltek, feltehetően a XVIII. század közepétől. [...] A juhtenyésztő vajnafalvi románok messze földön ismertek voltak jó minőségü készítményeikről. Nemcsak a tejtermékek (túró, sajt, orda, sós tej) tették híressé őket, hanem a gyapjúfeldolgozás is, amit házilag végeztek, kézi erôvel megfonták, majd megszôtték. A kovásznai posztó mindenfelé keresett termék volt, különösen a második világháború után." (Dr. Benkő Gyula - Fábián Ernő 2007. 22-23.)

Kozma Ferenc 1879-es leírásában az áll, hogy Kovásznán 12-en állandóan, 16-an ide- iglenesen foglalkoztak gyapjúfeldolgozással. „Az 1885-ös budapesti országos kiállításon mint fontos terméket szerezték be a kovásznai híres halinaposztót és pokrócokat. Ez jórészt fehér és szürke, durva posztó volt, amelyet elsősorban a felsô ruházathoz vásároltak a vidék kereskedői. [...] A marosvásárhelyi kereskedelmi és iparkamara 1899-es felmérése Kovásznán 4 posztóverōt tartott nyilván és a helység híres csergéjét e neves ipari fórumon is számon tartotta. A millenniumi évkönyv két posztóványolót tartott nyilván Kovásznán és azt is jelezte, hogy igény volt a századfordulón a gyapjúszőttesek finomítására. Az 1907-es sepsiszentgyörgyi székely kiállításon is részt vettek a vajnafalvi román gyapjúszövők." (Szőcsné Gazda Enikő 2007).

A kisipari egyesületek létrejöttét az 1910-es években jegyzik, ekkor 3 gyapjúfeldolgozó múködött: a Mioriţa Vajnafalván, valamint a Hangya és a Szorgalom szövetkezet néven Kovásznán. A tulajdonképpeni gyáripar 1923-ban jelenik meg, ezeknek az egyesületeknek a folytatásaként.

A kereskedelmi kamara bejegyzése szerint Kovásznán 1926-1952 között működött a Kisipari mesterek általános testülete, amelyhez 4 takácsmester csatlakozott (Ioan Lăcătuşu 2009. 165.).

Dokumentumok szerint az ún. első román világban már három posztógyár üzemelt a városban, de az adatközlők emlékei szerint a „fileturában” nem szőttek, csak előkészítették az anyagot, pontosabban ványoltak, fes- 
tettek, fontak. Ez a gyár később Prázsmárhoz tartozott, és az 1980-as években a kommandói „perzsaszövődét” is innen látták el gyapjúval (Bede Levente).

Jelenleg Kovászna megyében sehol nem ványolnak. A kovásznai gyapjúgyár részére Bákóban végzik el a munkálatokat (Bede Levente).

1930-1944 között Vajnafalván Papuc Gheorghe, Maria Jurebita (Teaca), Ioan Rusu és Raveica Urzică üzemeltette a Buru néven ismert posztógyárat - jelenleg is ezen a néven ismerik, ahol 4 fonógép, 3 ványoló és 4 szövőszék volt üzembe helyezve (Ioan Lăcătuşu, 2009, 168.).

Itt jegyezzük meg, hogy ez a gyár a Horea, Cloşca şi Crişan utcában az államosítás után 2001-ig működött.

A Kereskedelmi Kamara és Ipartestület bejegyzései szerint 1934-től 1948-ig üzemelt Péterffy Adalbert posztógyára, a Petőfi utcában, amely jelenleg is Filatura néven ismeretes.

Ugyanott jegyzik Csutak Lajos és Csutak Ferenc szövő- és fonógyárát a Gábor Áron utcában, amelyik később Béke gyár néven vált ismerté. Ez kezdetben takaros kisüzem volt. A szövőszékeket gőzüzemű meghajtásra szerelték fel. A gőzgépek transzmissziós szíjakkal voltak ellátva, amelyeket a tetőtéri padláson vezettek át.

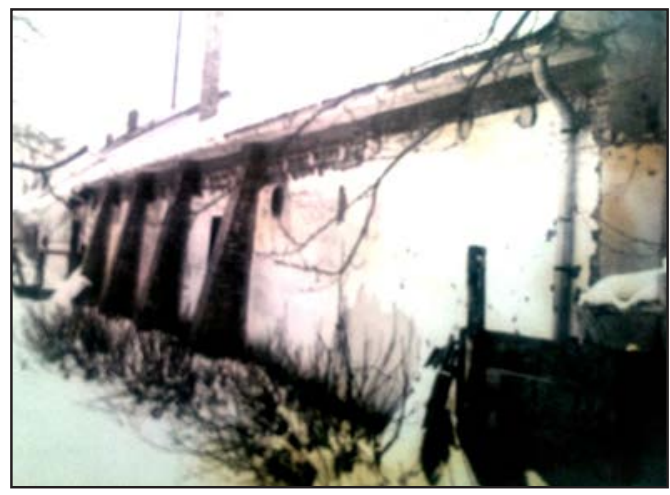

1.kép. Posztógyár 1936-ban (archív felvétel)
A kezdeti időszakból fennmaradt egy Németországban gyártott kártológép és egy előfonalgyártó.

Valószínű, hogy a szövőszékek is Németországból érkeztek, de bővebb információval nem rendelkezünk. Az adatközlők szerint a kommunizmus éveiben már „EVELINA” és „MUGUREL” cégjegyzésű vetélős szövőgépekkel dolgoztak.

Ekkoriban sokféle anyagot szőttek, például: posztót, szőnyeget, pokrócot, törülközőanyagokat, szőttesféleségeket, sőt egész vékony szálú ún. „ije” anyagokat is szőttek az „aba” posztón kívül. A kovásznai háziiparosoknak köszönhetően a posztógyártás kisipari jellegét a gyáripar megjelenése után is megtartotta. Az adatközlők emlékei szerint az államosítás után egyesítették a háziipart a gyárakkal, mindenki bevitte a gépeit, a nyersanyagot és a szaktudását a közösbe. Innen ered a sokatmondó Béke gyár megnevezés. Voltak bedolgozó munkások, akik otthon dolgoztak (Bede Levente).

Beke Ernő munkájában a kovásznai posztókészítésről az alábbi bejegyzést olvashatjuk:

„Kovászna talán leghíresebb kisipari termékei a különféle posztók és gyapjúszövetek voltak. Nyersanyag böségesen és olcsón állt rendelkezésre. Szinte nem volt ház, ahol ne foglalkoztak volna szövés-fonással mind a románok, mind a magyarok. Voltak olyan kisüzemek, ahol már árutermelés folyt. A finom négy-hat-, sôt nyolcnyüstös szöveteket nagyvárosok (Brassó, Bukarest, Kolozsvár) kereskedői forgalmazták. Fésülők, préselők és ványolók múködtek a szövőmúhelyek kiszolgálására. Legjelentôsebbek a Péterffi (volt Pálmay), Csutak Lajos és Csutak Ferenc fonóés szövőgyárai, de rajtuk kívül voltak olyan háziipari mühelyek, mint Bogyó, Cseh, Bede és Orbán (finom vásznakat is készített) szövődék 


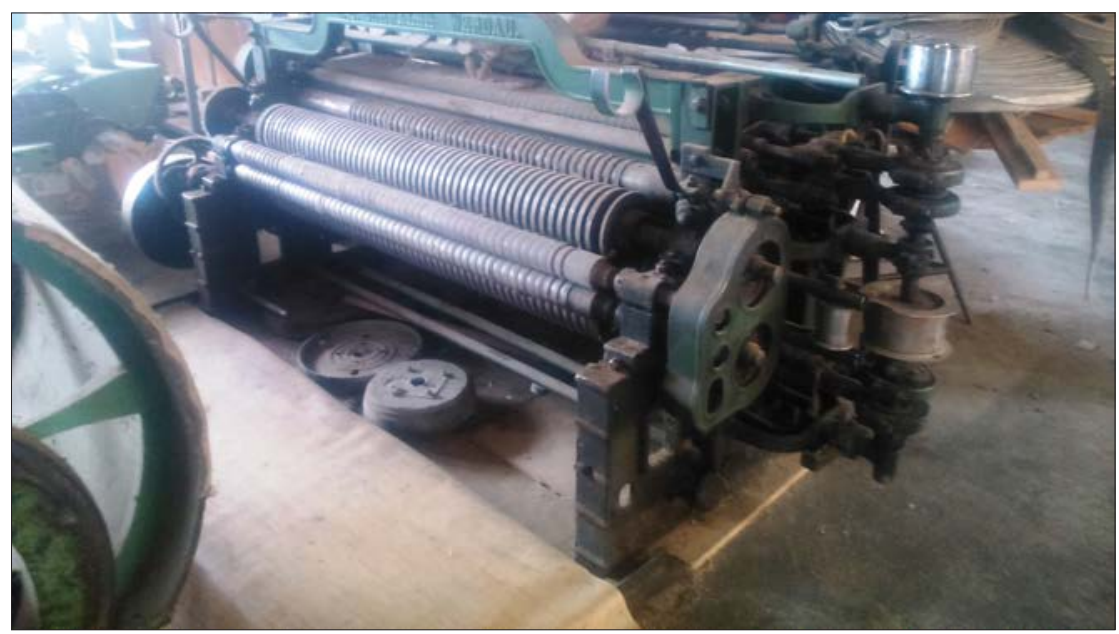

2. kép. Egy 1901-ben gyártott tépetőgép

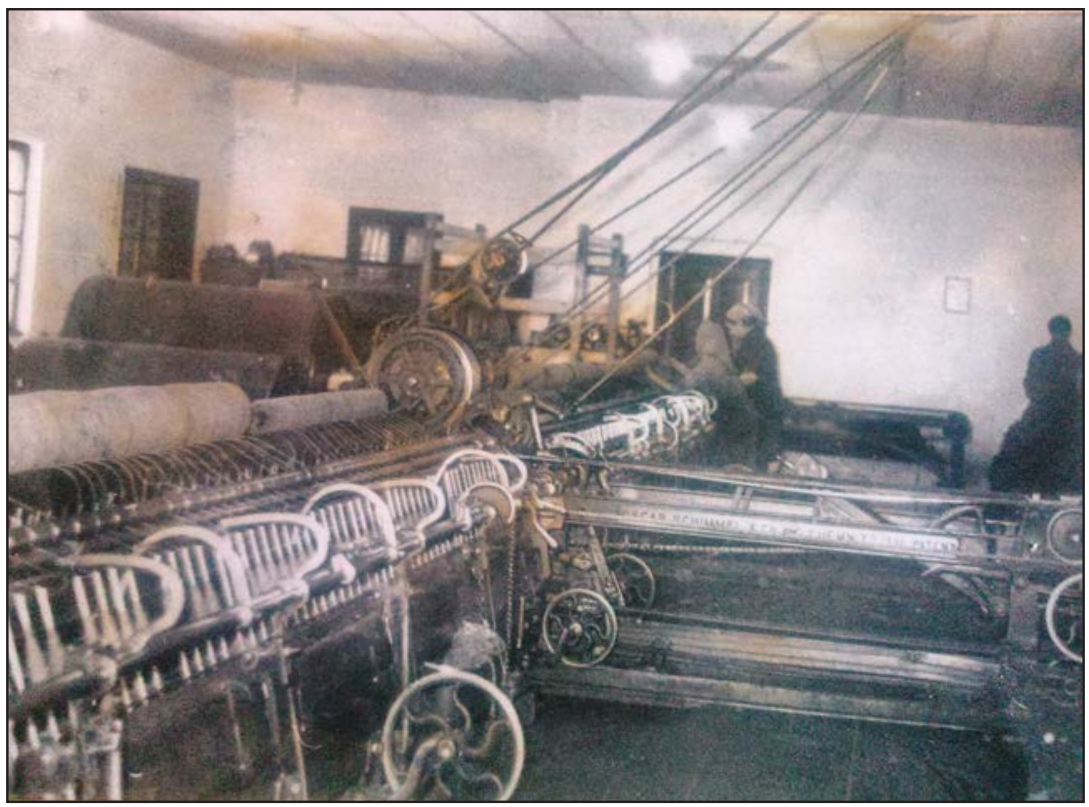

3. kép. Szövőszékek anno (archív felvétel)

és fésülő-ványolók, ahol szintén minőségi árut termeltek." (Beke Ernő 2005, 10.)

A kovásznai posztógyárakat 1989 után apránként felszámolták, jelenleg a hajdani Béke gyár épületében egy magánvállalkozó (Ciambur Dan) öt emberrel dolgoztat, és csak ha- gyományos, eredeti színú abaposztót szőnek. Az adatközlők szerint napjainkban senki más nem foglalkozik gyapjúfeldolgozással, sem posztószövéssel. A vállalkozó a régi gépeket megtartotta, jelenleg is üzemképesek és megtekinthetők. 


\section{Felhasznált irodalom}

Beke Ernő: Üdvözlet háromszékről. Charta kiadó, Sepsiszentgyörgy, 2005.

Benkő Gyula - Fábián Ernő: Kovászna. Charta kiadó Sepsiszentgyörgy, 2007.

Lăcătuşu, Ioan: Personalităţi ale Oraşului Covasna. Studiu monografic. Editura Eurocarpatica, Sf. Gheorghe, 2009.
Szőcsné Gazda Enikő: Gyapjúfeldolgozás, kendertermesztés. In: Kinda István - Pozsony Ferenc (szerk): Orbaiszék változó társadalma és kultúrája. Sepsiszentgyörgy, 2007. 155.

Adatközlő: Bede Levente, Kovászna. 